\title{
Sludge Treatment Project KOP Conceptual Design Control Decision Report
}

Prepared for the U.S. Department of Energy

Assistant Secretary for Environmental Management

Contractor for the U.S. Department of Energy

under Contract DE-AC06-08RL14788

CH2MHILL

Plateau Remediation Company

P.O. Box 1600

Richland, Washington 99352

Approved for Public Release;

Further Dissemination Unlimited 
PRC-STP-00206

Revision 0

EDC \#: PRC-EDC-10-45106

\section{Sludge Treatment Project KOP Conceptual Design Control Decision Report}

Project No: STP

Document Type: RPT

Program/Project: STP

C. A. Carro

Authorization Basis Services, Inc.

Date Published

March 2010

Prepared for the U.S. Department of Energy

Assistant Secretary for Environmental Management

Contractor for the U.S. Department of Energy

under Contract DE-AC06-08RL14788

\section{CH2MHILL}

Plateau Remediation Company

P.O. Box 1600

Richland, Washington
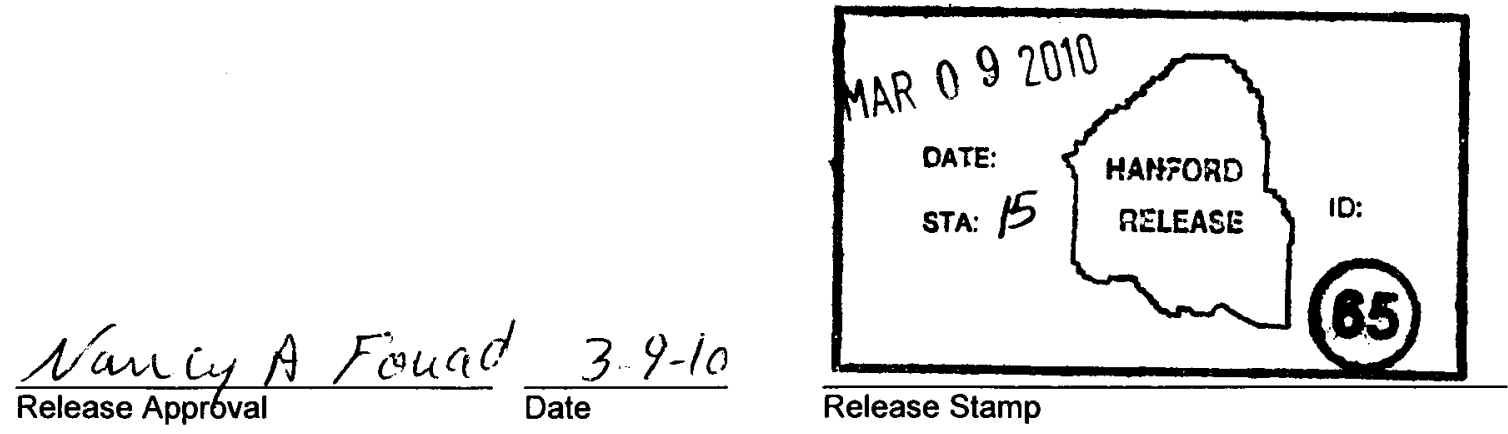

Release Stamp 
PRC-STP-00206

Revision 0

TRADEMARK DISCLAIMER

Reference herein to any specific commercial product, process,

or service by trade name, trademark, manufacturer, or

otherwise, does not necessarily constitute or imply its

endorsement, recommendation, or favoring by the United

States Government or any agency thereof or its contractors or subcontractors.

This report has been reproduced from the best available copy.

Printed in the United States of America

Total Pages: 58 


\section{CONTENTS}

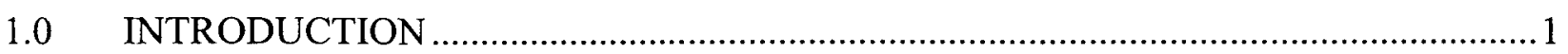

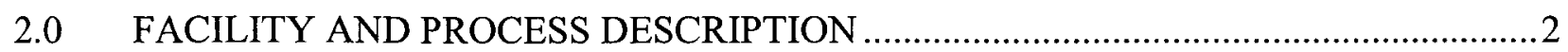

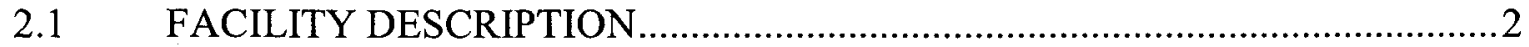

2.1.1 Primary Clean Machine .........................................................................

2.1.2 Screened Separations Table ................................................................

2.1.3 Verification Containers......................................................................

2.1.4 MCO Baskets and Copper Inserts..........................................................

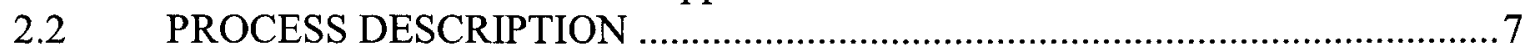

2.2.1 KOP Washing in the Primary Clean Machine ..........................................

2.2.2 Screened Separations Table Material Screening ...................................

2.2.3 Verification Container Filling and Density Verification .......................... 8

2.2.4 Copper Insert Filling and MCO Basket Loading, ,.................................8

3.0 ACCIDENT ANALYSIS results and comparison to guidelines........................................

3.1 ACCIDENT ANALYSIS RESULTS .........................................................

3.2 COMPARISON TO GUIDELINES …………..........................................11

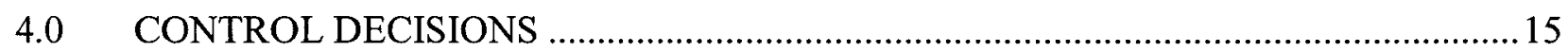

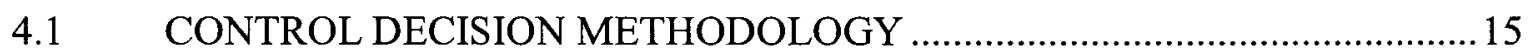

4.2 CONTROL DECISION RESULTS ……………...........................................15

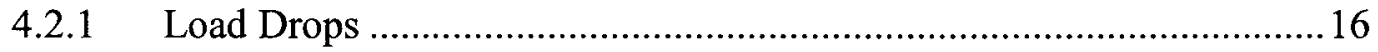

4.2.2 Spent Nuclear Fuel Overlift.............................................................17

4.2.3 Multi-Canister Overpack Thermal Runaway........................................17

4.2.4 Multi-Canister Overpack Internal Hydrogen Deflagration.................... 19

4.2.5 Multi-Canister Overpack Overpressurization.......................................21

4.2.6 Nuclear Criticality Safety ...............................................................24

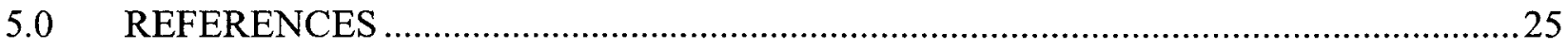

\section{APPENDICES}

A KOP DISPOSITION PROJECT CONCEPTUAL DESIGN ENGINEERING

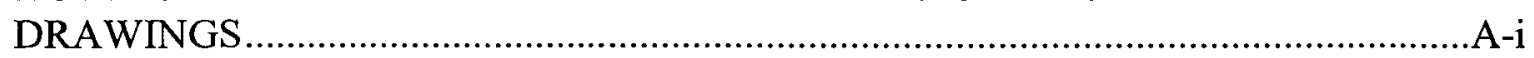

B CONTROL DECISION MEETING PARTICIPANTS ………..................................

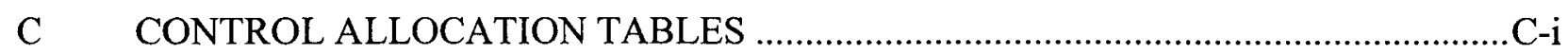




\section{FIGURES}

Figure 2-1. KOP Material Retrieval, Separation, and Sampling Equipoment and Process Overview...

Figure 2-2. Mark IA Scrap Basket and Copper Inserts

\section{TABLES}

Table 3-1. Conceptual Design Accident Analysis Consequences .................................................11

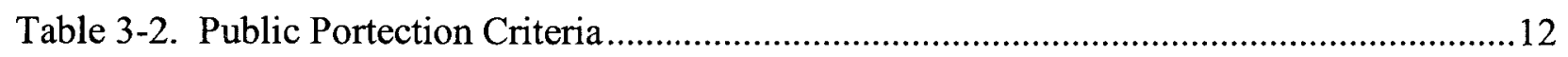

Table 3-3. Collocated Worker Protection Criteria, Radiological .............................................12

Table 3-4. Facility Worker Protection Criteria, Radiological ...................................................13

Table 3-5. Accident-Specific Safety Classification Requirement.............................................13

Table 4-1. Load Drop Engineered Controls.. …………......................................................

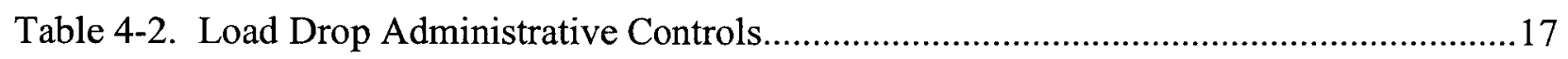

Table 4-3. MCO Thermal Runaway Engineered Controls .......................................................... 18

Table 4-4. MCO Thermal Runaway Administrative Controls ....................................................19

Table 4-5. MCO Internal Hydrogen Deflagration Engineered Controls .....................................20

Table 4-6. MCO Internal Hydrogen Deflagration Administrative Controls .................................21

Table 4-7. MCO Overpressurization Engineered Controls .........................................................22

Table 4-8. MCO Overpressurization Administrative Controls ……………………...................2 


\section{TERMS}

ARF

CHPRC

CSB

CSER

CVDF

IWTS

KOP

KPS

KW

MAR

$\mathrm{MCO}$

PCM

PISA

RF

SSCs

USQ
Airborne Release Fraction

CH2M HILL Plateau Remediation Company

Canister Storage Building

Criticality Safety Evaluation Report

Cold Vacuum Drying Facility

Integrated Water Treatment System

Knock-Out Pot

Knock-Out Pot Processing System

105-K West (Basin)

Material-at-Risk

Multi-Canister Overpack

Primary Clean Machine

Potential Inadequacy in the Safety Analysis

Respirable Fraction

Structures, Systems, and Components

Unreviewed Safety Question

$$
\text { ii v. }
$$




\subsection{INTRODUCTION}

This control decision addresses the Knock-Out Pot (KOP) Disposition KOP Processing System (KPS) conceptual design. The KPS functions to (1) retrieve KOP material from canisters, (2) remove particles less than $600 \mu \mathrm{m}$ in size and low density materials from the KOP material, (3) load the KOP material into Multi-Canister Overpack (MCO) baskets, and (4) stage the MCO baskets for subsequent loading into MCOs.

Hazard and accident analyses of the KPS conceptual design have been performed to incorporate safety into the design process. The hazard analysis is documented in PRC-STP-00098, Knock-Out Pot Disposition Project Conceptual Design Hazard Analysis. The accident analysis is documented in PRC-STP-CN-N-00167, Knock-Out Pot Disposition Sub-Project Canister Over Lift Accident Analysis. Based on the results of these analyses, and analyses performed in support of MCO transportation and MCO processing and storage activities at the Cold Vacuum Drying Facility (CVDF) and Canister Storage Building (CSB), control decision meetings were held to determine the controls required to protect onsite and offsite receptors and facility workers. At the conceptual design stage, these controls are primarily defined by their safety functions. Safety significant structures, systems, and components (SSCs) that could provide the identified safety functions have been selected for the conceptual design. It is anticipated that some safety SSCs identified herein will be reclassified based on hazard and accident analyses performed in support of preliminary and detailed design. 


\subsection{FACILITY AND PROCESS DESCRIPTION}

The KPS facility and process descriptions provided below are supported by engineering drawings in Appendix A. Figure A-1 is the process flow diagram. Figures A-2 through A-4 present the piping and instrumentation drawings. Figure 2-1 provides an overview of the KPS equipment and process. The engineering drawings in Appendix A are revisions of the drawings upon which the hazard analysis documented in PRC-STP-00098 was based. The principal change was the elimination of the oxide purge station. The drawing revisions were reviewed and it was determined that the changes do not introduce new hazardous conditions nor change the consequences of the previously identified hazards.

The separation function of the KPS is critical to the successful disposition of KOP material. The separation function has two functional requirements: (1) the removal of particles less than $600 \mu \mathrm{m}$, and (2) the removal of low-density, non-uranium materials. As discussed in KBC-38156, Conceptual Feasibility Report for KOP Accelerated Disposition, the removal of particles smaller than $600 \mu \mathrm{m}$ and non-uranium materials reduces the amount of hydrates that must be assumed in the material (which determines the quantity of chemically bound water), reduces the reactive surface area that must be assumed (which impacts the hydrogen generation rate, thermal stability, and the material at risk for $\mathrm{MCO}$ accidents), facilitates drying at the CVDF, and reduces the overall volume of material that must be loaded into MCOs.

\subsection{FACILITY DESCRIPTION}

The KPS will be comprised of existing and new equipment located in the West Bay of the 105-K West (KW) KW Basin. A description of the KW Basin can be found in HNF-SD-WM-SAR-062, KW Basin Final Safety Analysis Report, Chapter 2, Section 2.4.1.2, "105-KW Fuel Storage Basin." The principal existing equipment that will be used is the Primary Clean Machine (PCM), the Integrated Water Treatment System (IWTS), and MCO Mark 1A scrap baskets. New equipment includes screened canisters, a Screened Separations Table, a vacuum wand and associated low density collection strainers, Verification Containers, and MCO basket Copper Inserts.

\subsubsection{Primary Clean Machine}

The PCM is described in HNF-SD-WM-SAR-062, Chapter 2, Section 2.5.3.1, "Primary Clean Machine Equipment Description." The PCM was originally used to clean fuel and debris canisters. Recently, the PCM has been used to clean canisters of KOP material as part of in-basin KOP characterization activities, as described in HNF-SD-WM-SAR-062, Chapter 2, Section 2.5.8.3, "KOP, PCM Strainer, and IWTS Strainer In-Basin Characterization." 


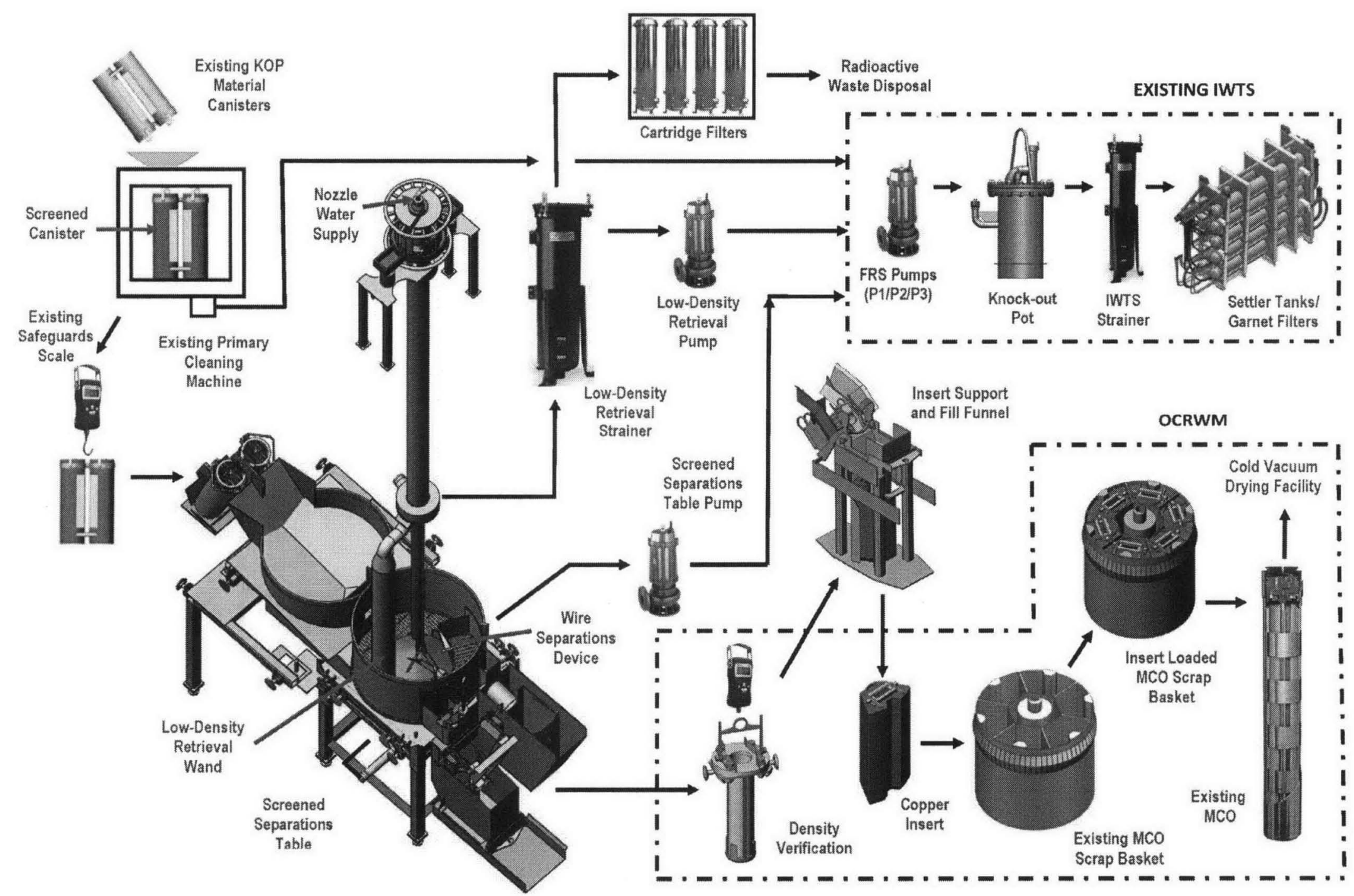

Figure 2-1. KOP Material Retrieval, Separations, and Sampling Equipment and Process Overview. 
The PCM includes the following equipment:

- Stationary outer enclosure box that houses the rotating fuel wash basket

- Wash basket drive assembly

- High-pressure flush nozzles

- Strainer basket located in the bottom of the PCM outer enclosure box

- Enclosure box water discharge pump housing

- Skid-mounted, high-pressure pump assembly and control valves

- PCM control station

- Hydraulic wash basket locking mechanism

- Fuel canister locating guides

- Fuel canister locking mechanism.

The stationary outer enclosure is a steel box. Hinges on one side allow the top of the box to be tipped up to gain access to the inside of the PCM. A two-piece cylindrical wash basket is mounted inside the enclosure. The wash basket, designed to hold a canister, is split in half with a joint allowing it to be opened by removing one half. The wash basket is rotated inside the enclosure by a drive mechanism. Water nozzles mounted inside the enclosure spray pressurized water through slots in the wash basket to flush out the sludge. A suction connection provides a continuous flow of water from the PCM enclosure to the IWTS. The IWTS is described in HNF-SD-WM-SAR-062, Chapter 2, Section 2.5.7.3, "Integrated Water Treatment System." Suction flow from the PCM is greater than pressurized water inflow to maintain basin water clarity.

For KPS use, KOP material will be washed in the PCM using a newly-designed, double-barreled screened canister. The screened canister openings will be a nominal $600 \mu \mathrm{m}$ in size. An agitator will be placed in the canister with the KOP material to breakup friable non-uranium components (e.g., grafoil, aluminum hydroxide) into smaller particles during the cleaning process.

\subsubsection{Screened Separations Table}

The Screened Separations Table will be comprised of a wedge wire screened region and a Verification Container loading area. The openings of the screened region will be a nominal $600 \mu \mathrm{m}$ in size. KOP material on the screened region will be moved and agitated using water spray nozzles and manual tools. Material smaller than $600 \mu \mathrm{m}$ that passes through the screened region of the table will be pumped to the IWTS.

Low density material will be vacuumed from KOP material on the screened region using a vacuum wand and pumped to a low density collection strainer. The flow velocity through the vacuum end effector will be controlled such that $600 \mu \mathrm{m}$ or larger uranium metal particles will not be collected. Particles collected by the vacuum wand that are less than $600 \mu \mathrm{m}$ will pass through the low density collection strainer and be pumped to the IWTS. Material collected on the strainer will be disposed of as radioactive waste.

The Verification Container loading area of the Screened Separations Table includes openings under which Verification Containers will be positioned. The openings will be normally plugged to prevent foreign material from collecting in a Verification Container. 


\subsubsection{Verification Containers}

The Verifications Containers are sized to hold approximately $1.3 \mathrm{~L}$ of KOP material.

The containers are provided with markings so Operators can determine the actual volume of KOP material in the container. The containers will be filled by moving KOP material to the openings in the Verification Container loading area of the Screened Separations Table. The Verification Containers are provided with a bail for manually moving and weighing the containers.

\subsubsection{MCO Baskets and Copper Inserts}

The KOP material will be loaded into Copper Inserts which fit into a Mark 1A scrap basket. Mark 1A scrap baskets, made of stainless steel and copper, are approximately 22.6 in. in diameter and $23.3 \mathrm{in}$. high with a center post of $6.63 \mathrm{in}$. in diameter. The bottom of the baskets is supported by a flat plate with holes to permit effective water and gas flow. The center post provides handling capability.

The Copper Inserts are fabricated with a slot to hold the KOP material. The slot is approximately $1 \mathrm{in}$. wide by $4.5 \mathrm{in.}$ long and $20.5 \mathrm{in}$. high (i.e., the entire height of the insert). The KOP material is held in the slot by a nominal $500 \mu \mathrm{m}$ screen at the bottom of the insert. After KOP material is transferred from a Verification Container to a Copper Insert, a $500 \mu \mathrm{m}$ top screen is put in place. The slots are sized to hold approximately $1.3 \mathrm{~L}$ of KOP material when the top and bottom screens are in place. A Mark 1A scrap basket will hold six Copper Inserts (see Figure-2-2).

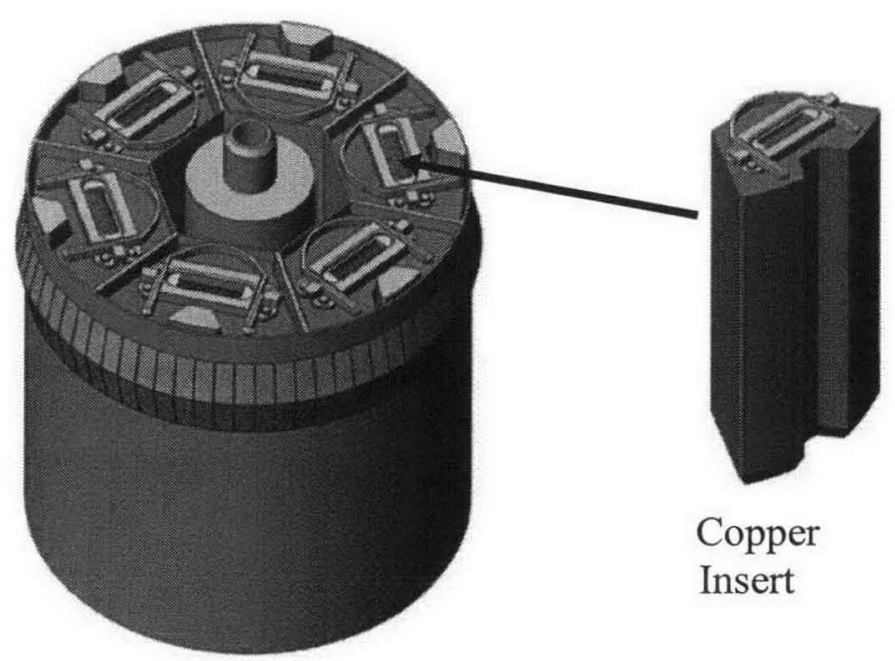

MCO Basket

Figure 2-2. Mark 1A Scrap Basket and Copper Inserts. 


\subsection{PROCESS DESCRIPTION}

\subsubsection{KOP Washing in the Primary Clean Machine}

As of February 2010, there is a total of approximately $815 \mathrm{~kg}$ of KOP material stored in canisters in the West Bay of the KW Basin. The KPS process starts with the transfer of KOP material to a screened canister. Each barrel of the double-barreled screened canister will be filled with approximately $10 \mathrm{~L}$ of KOP material. An agitator will be placed in each canister barrel along with the KOP material and a canister lid put in place. The canister will then be washed in the PCM. During the washing cycle, the agitator will function to breakup friable, non-uranium components (e.g., grafoil, aluminum hydroxide) into smaller particles. Particles, both uranium and non-uranium, less than $600 \mu \mathrm{m}$ in size will be washed out of the canister and into the IWTS.

After washing, the canister will be removed from the PCM and weighed using an existing safeguards scale. The canister will then be washed a second time and re-weighed. The wash/weigh cycle will be repeated until there is no appreciable weight loss. The KOP material is then ready for transfer to the Screened Separations Table.

\subsubsection{Screened Separations Table Material Screening}

After washing in the PCM, KOP material will be transferred to the screened region of the Screened Separations Table. Using water spray nozzles and manual tools, operators will move the KOP material over the $600 \mu \mathrm{m}$ screen in multiple passes. Any remaining particles less than $600 \mu \mathrm{m}$ in size will fall through the screen and be transferred to the IWTS.

Two additional activities will be performed in the screened region of the table, i.e., the removal of aluminum wires and the removal of other low density materials greater than $600 \mu \mathrm{m}$ in size. Aluminum wire was used on the bottom of several hundred canisters of fuel. When these fuel canisters were washed in the PCM, some of the wire was damaged and subsequently collected in KOPs. The other low density materials of principal concern are grafoil and aluminum hydrates. Grafoil was used as a seal on the fuel canister lids. Aluminum hydrates were formed on the surfaces of aluminum fuel canisters during years of storage. The purpose of removing these materials is to increase the bulk density of the KOP material, which is used to determine the quantity of chemically bound water ultimately loaded into an MCO.

To remove the aluminum wire fragments and low density materials, operators will move the KOP material over a small section of course screen (e.g., 1/8 - 3/16 in. perforations). After this pre-screening, the wire fragments and low density materials will be removed from the KOP material with the vacuum wand.

As previously stated, the flow velocity through the vacuum end effector will be controlled such that uranium metal particles $600 \mu \mathrm{m}$ and larger in size will not be collected. Low density particles and aluminum wire fragments collected by the vacuum wand that are greater than $600 \mu \mathrm{m}$ will be collected on the low density collection strainer. A radiation detector will be used to verify that material collected on the strainer can be disposed of as radioactive waste. Material that passes through the low density collection strainer will be transferred to the IWTS. 
After the KOP material has been screened, and aluminum wire and low density materials have been removed, it is ready for transfer to the Verification Container loading area of the Screened Separations Table.

\subsubsection{Verification Container Filling and Density Verification}

Empty Verification Containers, once placed in the basin water, will be weighed to obtain a tare weight. They will then be pre-positioned under the openings of the Verification Container loading area of the Screened Separations Table. Plugs in the openings prevent foreign material from dropping into the containers. When KOP material has been screened and low density materials removed, the plugs will be removed from the openings and the KOP material will be sluiced or pushed over the openings using the spray nozzles or manual tools.

Filled Verification Containers will be removed from their fixtures under the Screened Separations Table and weighed. From the known volume and measured mass, the bulk density of the KOP material will be calculated. If the calculated bulk density is lower than a target density, the material in the container may be returned to the PCM for additional size reduction or transferred back to the Screened Separations Table for additional processing. If the material equals or exceeds the target density requirement, it is ready for transfer to a Copper Insert.

\subsubsection{Copper Insert Filling and MCO Basket Loading,}

KOP material that meets the bulk density requirement will be transferred to a Copper Insert by use of a fill funnel. The fill funnel will be positioned over the slot of a Copper Insert and the Verification Container manually tipped such that the KOP material falls into the slot. The material is held in the slot at the bottom by a $500 \mu \mathrm{m}$ screen.

When the KOP material has been loaded into the Copper Insert slot, a $500 \mu \mathrm{m}$ top screen will be put in place. It has not yet been determined whether the Copper Inserts will first be filled with $\mathrm{KOP}$ material and then loaded into an MCO basket, or if empty Copper Inserts will be placed in an MCO basket and then filled. 
PRC-STP-00206 REV 0

3.0

ACCIDENT ANALYSIS RESULTS AND COMPARISON TO GUIDELINES

\subsection{ACCIDENT ANALYSIS RESULTS}

The hazardous conditions identified in PRC-STP-00098 with the potential for an uncontrolled release are:

- Load Drop

- Spent Nuclear Fuel Overlift

- MCO Overpressurization

- MCO Internal Hydrogen Deflagration

- MCO Thermal Runaway.

As stated in PRC-STP-00098, the spent nuclear fuel overlift and load drop hazardous conditions are not new or unique to the KPS. Spent nuclear fuel overlifts and load drops of fuel canisters and MCO baskets were identified and evaluated in the HNF-3960, K Basins Hazard Analysis, and are analyzed as design basis accidents in HNF-SD-WM-SAR-062. A spent nuclear fuel overlift accident specific to KOP material in a fuel canister is analyzed in PRC-STP-CN-N-00167.

It is important to note that the MCO overpressurization, deflagration, and thermal runaway accidents do not occur during KPS activities. The overpressurization and deflagration accidents potentially exist once the MCOs are loaded and ready for transport to the CVDF and CSB, and a thermal runaway accident is only credible at CVDF. However, the frequency and consequences of these accidents are dictated, in large part, by the quantity and physical and chemical characteristics of the KOP material that is loaded into the MCO baskets. Therefore, KPS activities must be controlled to prevent unacceptable accident consequences or unanalyzed accident conditions during subsequent $\mathrm{MCO}$ processing at $\mathrm{CVDF}$, storage at $\mathrm{CSB}$, and during inter-facility transfers. The overpressurization, deflagration, and thermal runaway design basis accidents with the bounding consequence are documented in HNF-3553, Volume 3, Annex B, Cold Vacuum Drying Facility Final Safety Analysis Report.

Table 3-1 presents the consequences of the load drop, spent nuclear fuel overlift, and MCO overpressurization, deflagration, and thermal runaway design basis accidents. A summary of each accident scenario is provided below:

- Load Drop: Load drop accidents are analyzed in HNF-SD-WM-SAR-062, Section 3.4.2.1, "105-KW Heavy Load Drops." As described in HNF-SD-WM-SAR-062, the scenario is an accidental drop of a heavy load into the basin or onto the basin floor due equipment failure, human error, or a seismic event. The drop of an MCO basket or knockout pot during normal operations is specifically addressed as is the drop of an MCO basket while loading the MCO. No consequences are calculated because the drops do not perforate the basin floor when credit for controls is taken.

- Spent Nuclear Fuel Overlift: As described in PRC-STP-CN-N-00167, the scenario is the overlift of a KOP canister out of the basin water due to human error or equipment failure. It is assumed that each barrel of the double-barreled canister contains $12 \mathrm{~L}$ of KOP material. The uranium metal in the KOP reacts with water to form $\mathrm{UO}_{2}$ and reaches 
a temperature of $100^{\circ} \mathrm{C}$. The material-at-risk is $12.6 \mathrm{~kg} \mathrm{UO}_{2}$ which is the quantity of uranium oxide generated during 2 -hour release duration at $100^{\circ} \mathrm{C}$. The airborne release fraction (ARF) and respirable fraction (RF) are $2.0 \times 10^{-3}$ and 1.0 , respectively.

- MCO Ovepressurization: An MCO overpressurization is analyzed in HNF-3553, Volume 3, Annex B, Section B.3.4.2.6, "Multi-Canister Overpressurization." The accident is assumed to begin during or following the water draining process, with some undrained water still present in the MCO to react with the fuel. The water reacts with uranium and uranium hydride producing hydrogen gas that pressurizes the MCO. Given sufficient time and water, the reactions will eventually lead to an increase in pressure sufficient to breach the MCO. The blowdown of particulate is assumed through a breach assumed to be an opening 1-in. in diameter at a pressure of $345 \mathrm{psig}$. The MAR for the blowdown is $57.2 \mathrm{~kg}$ of uranium and the ARF/RF is $2 \times 10^{-3}$. After the blowdown, there is a $2-\mathrm{hr}$ continuous release as the fuel-water reactions continue. The MAR for the continuous release is $3.5 \mathrm{~kg}$ of uranium and the ARF/RF is $8 \times 10^{-6}$.

- MCO Internal Hydrogen Deflagration: An MCO internal hydrogen deflagration is analyzed in HNF-3553, Volume 3, Annex B, Section B.3.4.2.4, "Multi-Canister Overpack Internal Hydrogen Deflagration." Hydrogen is generated in the MCO during processing at CVDF. Given multiple failures of equipment and process monitoring, significant quantities of oxygen and hydrogen could accumulate inside an MCO during the drain and purge/flush, drying, proof, and pressure test portions of the CVDF process. An ignition source is assumed to be present in the MCO. The deflagration pressurizes the MCO and particulate material is blown-out through a line break or a rupture disk. The MAR is $27.2 \mathrm{~kg}$ of uranium. The ARF $/ \mathrm{RF} 2 \times 10^{-3}$.

- MCO Thermal Runaway: An MCO thermal runaway is analyzed in HNF-3553, Volume 3, Annex B, Section B.3.4.2.5, "Multi-Canister Overpack Thermal Runaway Reaction." Thermal runaway reaction accidents can occur if heat removal from the MCO is not sufficient to prevent the fuel form heating up as a result of decay heat and chemical reaction heat. As the temperature increases, the chemical reaction rate also increases. If the reaction were allowed to continue, the temperature would continue to increase until the water was consumed by the fuel-water reaction. The MCO thermal runaway is assumed to begin when the water draining process is finished but some residual water is still present to react with the fuel. Thermal calculations predict that the fuel could reach temperatures in excess of $700^{\circ} \mathrm{C}$. The maximum MCO wall temperature is less than $540^{\circ} \mathrm{C}$, which will not result in structural damage to the MCO. The MAR is $19.3 \mathrm{~kg}$ of uranium. The ARF/RF is $5 \times 10^{-3}$. 
Table 3-1. Conceptual Design Accident Analysis Consequences

\begin{tabular}{|l|l|c|c|c|}
\hline \multirow{2}{*}{ Accident } & \multirow{2}{*}{ Facility } & \multicolumn{3}{c|}{ Consequences (rem, TEDE) } \\
\cline { 3 - 5 } & & $\begin{array}{c}\text { Facility } \\
\text { Worker }\end{array}$ & Onsite & Offsite \\
\hline Load Drop & KW Basin & $\begin{array}{c}\text { Not } \\
\text { calculated }\end{array}$ & $\begin{array}{c}\text { Not } \\
\text { calculated }\end{array}$ & $\begin{array}{c}\text { Not } \\
\text { calculated }\end{array}$ \\
\hline Nuclear Fuel Overlift & KW Basin & H & 90 & 0.22 \\
\hline MCO Overpressurization & CVDF & H & 1,200 & 0.75 \\
\hline $\begin{array}{l}\text { MCO Internal Hydrogen } \\
\text { Deflagration }\end{array}$ & CVDF & H & 580 & 0.36 \\
\hline MCO Thermal Runaway & CVDF & H & 175 & 0.44 \\
\hline
\end{tabular}

*Load drop accident consequences are not calculated in HNF-SDWM-SAR-062 because the accident is prevented.

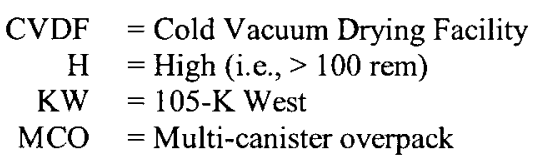

The MCO overpressurization, deflagration, and thermal runaway accident consequences presented in Table 3-1 are based on material-at-risk (MAR) values derived for an MCO containing spent nuclear fuel. In each case, the MAR is the mass of uranium dioxide $\left(\mathrm{UO}_{2}\right)$ available for dispersion. A comparison of the spent nuclear fuel MCO MAR with an estimated KOP MCO MAR is presented in PRC-STP-00127, Basket Washing and KOP Material at Risk Discussion. Assuming the total volume of the Copper Insert slots in three MCO baskets is completely filled with $\mathrm{UO}_{2}$, and using the same safety basis processing times and temperatures, the MAR increases from approximately $40 \mathrm{~kg}$ for a spent nuclear fuel $\mathrm{MCO}$ to approximately $60 \mathrm{~kg}$ for a KOP MCO. If all of the uranium metal in a KOP MCO was non-mechanistically converted to $\mathrm{UO}_{2}$, the MAR would be $180 \mathrm{~kg}$. In this hypothetical case, a portion of the $\mathrm{UO}_{2}$ generated would overflow the Copper Inserts due to the volume expansion associated with conversion from uranium metal to $\mathrm{UO}_{2}$.

In addition to the design basis accidents analyzed in the KW Basin, CVDF, and CSB safety bases, HNF-SD-TP-SARP-017, Safety Analysis Report for Packaging (Onsite) Multi-Canister Overpack Cask, addresses potential accidents during transportation.

\subsection{COMPARISON TO GUIDELINES}

Guidelines for the safety classification of SSCs are established in DOE-STD-3009-94, Preparation Guide for U.S. Department of Energy Nonreactor Nuclear Facility Documented 
Safety Analyses, and DOE-STD-1189-2008. The public and collocated worker protection criteria are presented in Tables 3-2 and 3-3.

Table 3-2. Public Protection Criteria

\begin{tabular}{|c|c|}
\hline Safety Class Controls & $\begin{array}{c}\text { Unmitigated Consequence } \\
\text { (TEDE) }\end{array}$ \\
\hline Required & $>25 \mathrm{rem}$ \\
\hline To be considered & $\geq 5 \mathrm{rem}$ \\
\hline
\end{tabular}

$\mathrm{TEDE}=$ total effective dose equivalent.

Table 3-3. Collocated Worker Protection Criteria, Radiological.

\begin{tabular}{|c|c|}
\hline Safety Significant Controls & $\begin{array}{c}\text { Unmitigated Consequence } \\
\text { (TEDE) }\end{array}$ \\
\hline Required & $>100 \mathrm{rem}$ \\
\hline
\end{tabular}

$\mathrm{TEDE}=$ total effective dose equivalent.

The facility worker protection criteria are as follows:

- significant exposure of the facility worker to radiological or other hazardous materials

- energetic releases of high concentrations of radiological or toxic materials where the facility worker would normally be immediately present and may be unable to take self-protective actions

- deflagrations or explosions within process equipment or confinement and containment structures or vessels where serious injury or death to a facility worker may result from the fragmentation of the process equipment or confinement/containment failing with the facility worker close by

- chemical or thermal burns to the a facility worker that could reasonably cover a significant portion of the facility worker body where self-protective actions are not reasonably available due to the speed of the event or where there may be no reasonable warning to the facility worker of the hazardous condition

- leaks from process systems where asphyxiation of a facility worker normally present may result.

Relative to a significant exposure to radiological materials, DOE-STD-1189-2008 provides the guidance presented in Table $3-4$. 
Table 3-4. Facility Worker Protection Criteria, Radiological

\begin{tabular}{|c|c|}
\hline Safety Significant Controls & $\begin{array}{r}\text { Unmitigated Consequence } \\
\text { (TEDE) }\end{array}$ \\
\hline Required & Clearly $>100 \mathrm{rem}$ \\
\hline To be considered & Approximately $100 \mathrm{rem}$ \\
\hline Not required & Clearly $<100 \mathrm{rem}$ \\
\hline
\end{tabular}

$\mathrm{TEDE}=$ total effective dose equivalent.

Calculating the precise radiological exposure to a facility worker is notoriously difficult since such calculations are very sensitive to the specific location of the facility worker relative to the release, the magnitude and respirable characteristics of the release, and the exposure duration. It is assumed, therefore, that the facility worker radiological consequences are a factor of 3 to 4 greater than the collocated worker for easily recognized events where the facility worker can be reasonably assumed to evacuate.

Comparing the radiological consequences presented in Table 3-1 with the above guidelines defines the accident-specific safety classification requirements for the conceptual design, which are presented in Table 3-5.

Table 3-5. Accident-Specific Safety Classification

Requirements

\begin{tabular}{|l|l|}
\hline \multicolumn{1}{|c|}{ Accident } & Safety Classification \\
\hline Load Drop & Safety Significant $^{1}$ \\
\hline Nuclear Fuel Overlift & Safety Significant $^{2}$ \\
\hline MCO Overpressurization & Safety Significant \\
\hline $\begin{array}{l}\text { MCO Internal Hydrogen } \\
\text { Deflagration }\end{array}$ & Safety Significant \\
\hline \begin{tabular}{l} 
MCO Thermal Runaway \\
\hline
\end{tabular} & Safety Significant \\
\hline
\end{tabular}

${ }^{1}$ As documented in HNF-SD-WM-SAR-062, load drop controls that prevent basin damage are safety significant

${ }^{2}$ Safety significant for facility worker safety 
As discussed in Section 3.1, the potential exists for a KOP MCO to have a larger MAR than a spent nuclear fuel $\mathrm{MCO}$, and thus higher accident consequence. However, accounting for such increases (e.g., from $40 \mathrm{~kg}$ to $60 \mathrm{~kg}$ ) the offsite dose consequences are still below the evaluation guidelines for the consideration of safety class structures, systems, and components. 
PRC-STP-00206 REV 0

\subsection{CONTROL DECISIONS}

\subsection{CONTROL DECISION METHODOLOGY}

A control decision meeting was held to select controls for the conceptual design. The control selection team was comprised of Safety-in-Design Integration team members from the following organizational disciplines:

- Operations

- Engineering

- Industrial Safety and Health

- Radiological Control

- Nuclear Safety.

Additional attendees included representatives from the CH2M HILL Plateau Remediation Company Engineering and Nuclear Safety organizations. A listing of attendees is provided in Appendix B.

Controls were selected by the team using the following DOE-STD-1189-2008 control selection order of preference:

- Minimization of hazardous materials is the first priority

- Safety SSCs are preferred over administrative controls

- Passive SSCs are preferred over active SSCs

- Preventive controls are preferred over mitigative controls

- Facility safety SSCs are preferred over personnel protective equipment

- Controls closest to the hazard may provide protection to the largest population of potential receptors, including workers and the public

- Controls that are effective for multiple hazards can be resource-effective.

Controls were selected for a given hazard analysis entry by first identifying general safety functions based on the causes and consequences of the hazardous condition. The conceptual design was then reviewed to identify SSCs which could meet the safety function. It is important to note that the hazard analysis, the associated accident analysis, and this control decision are based on a conceptual design. It is expected that the safety functions and safety SSCs identified herein will change as the design matures and new hazard and accident analyses of the revised design are performed.

\subsection{CONTROL DECISION RESULTS}

The following sections identify the engineered and administrative controls selected for the prevention and mitigation of load drop, spent nuclear fuel overlift, and MCO overpressurization, internal hydrogen deflagration, and thermal runaway accidents. Appendix B provides the 
detailed control allocation tables for the MCO overpressurization, internal hydrogen deflagration, and thermal runaway accidents. All safety SSCs will be procured, inspected and accepted, and verified in accordance with the requirements of PRC-MP-QA-599, Quality Assurance Program. All safety SSCs will undergo acceptance testing and start-up testing in accordance with PRC-PRO-EN-286, Testing of Equipment and Systems.

\subsubsection{Load Drops}

As discussed in Section 3.1, load drop accidents are not new or unique to the KPS. Load drop accidents are analyzed in the current KW Basin safety basis, and engineered and administrative controls have been implemented to prevent load drop accidents. Tables 4-1 and 4-2 present these existing engineered and administrative controls relative to KPS activities.

Table 4-1. Load Drop Engineered Controls

\begin{tabular}{|c|l|l|l|}
\hline $\begin{array}{c}\text { Item } \\
\text { No. }\end{array}$ & \multicolumn{1}{|c|}{ Safety Function } & Safety Significant SSCs & \multicolumn{1}{c|}{ Functional Requirements } \\
\hline 1 & $\begin{array}{l}\text { Prevent basin } \\
\text { perforation by } \\
\text { limiting the drop } \\
\text { height of the MCO } \\
\text { basket }\end{array}$ & MCO basket stiffback* & $\begin{array}{l}\text { 1. The MCO basket stiffback shall be } \\
\text { sufficiently long to prevent raising a loaded } \\
\text { MCO out of the basin water (regardless of } \\
\text { the hoist design or any hoist or operator } \\
\text { failures). } \\
\text { The MCO basket stiffback shall be } \\
\text { sufficiently long to ensure the MCO basket } \\
\text { drop height is limited to the analyzed value } \\
\text { in HNF-2229, Fuel Retrieval Sub-Project } \\
\text { Design Analysis Report for Safety Class } \\
\text { In-Pool Equipment- Volumes I, II, and III. } \\
\text { Note: The above functional requirements are } \\
\text { documented in HNF-SD-WM-SAR-062, } \\
\text { Section 4.3.4.3, "Functional Requirements." }\end{array}$ \\
\hline
\end{tabular}

*The MCO basket stiffback is classified as Safety Class in HNF-SD-WM-SAR-062 for prevention of nuclear criticality. The Safety Class designation is historical in nature and is not driven by current evaluation guidelines. 
Table 4-2. Load Drop Administrative Controls

\begin{tabular}{|c|c|c|c|}
\hline $\begin{array}{c}\text { Item } \\
\text { No. }\end{array}$ & Safety Function & Administrative Control & Remarks \\
\hline 1 & $\begin{array}{l}\text { Prevent separation or } \\
\text { perforation of the } 105-\mathrm{K} \text { West } \\
\text { Basin floor }\end{array}$ & $\begin{array}{l}\text { For lifts over the } 105-\mathrm{KW} \\
\text { Basin, the maximum allowable } \\
\text { load to be lifted shall not } \\
\text { exceed the load criteria listed } \\
\text { in Chapter } 3.0 \text {, Table } 3-10 \text {, of } \\
\text { HNF-SD-WM-SAR- } 062 \text {, or on } \\
\text { a case-by-case basis as } \\
\text { described in Section } 3.4 .2 .1 .3 \\
\text { of HNF-SD-WM-SAR- } 062 \text {, or } \\
\text { as approved by the Vice } \\
\text { President, KBC Project, the } \\
\text { maximum load allowed by the } \\
\text { (independently reviewed) } \\
\text { analysis that shows that a drop } \\
\text { of the load will not result in } \\
\text { perforation of the Basin Floor. }\end{array}$ & $\begin{array}{l}\text { The stated administrative control is } \\
\text { documented in } \\
\text { HNF-SD-SNF-TSR-001, K Basin } \\
\text { Technical Safety Requirements, } \\
\text { Section 5.9.2.9, "105-KW Heavy Load } \\
\text { Controls." }\end{array}$ \\
\hline
\end{tabular}

\subsubsection{Spent Nuclear Fuel Overlift}

As discussed in Section 3.1, spent nuclear fuel overlift accidents are not new or unique to the KPS. Overlifts of an MCO scrap basket, MCO fuel basket, PCM wash basket, and a KOP are addressed in HNF-SD-WM-SAR-0062. However, the overlift of a canister containing KOP material is not explicitly analyzed in HNF-SD-WM-SAR-0062 and was recently the subject of a Potential Inadequacy in the Safety Analysis (PISA) determination. As documented in PISA Determination 0322-2009, "Overlift of Canister Containing KOP Material," the overlift was determined to represent a PISA because it was judged to represent a hazardous condition not considered in the safety basis with the potential for significant impact to workers, the public, or environment. The associated Unreviewed Safety Question (USQ) determination (i.e., USQ Determination 0341-2009, “Overlift of Canister Containing KOP Material”) concluded that the overlift constitutes a positive USQ because of the possibility of an accident of a different type and an associated reduction in the margin of safety.

In response to the positive USQ determination, the KW Basin Nuclear Safety organization will develop a safety basis change in accordance with the requirements of PRC-PRO-NS-062,

Unreviewed Safety Question Process. Development of the safety basis change will include the identification of engineered and/or administrative controls to prevent and/or mitigate the overlift accident. The controls identified in the safety basis change will be adopted by the KOP Disposition Project.

\subsubsection{Multi-Canister Overpack Thermal Runaway}

The bounding MCO thermal runaway design basis accident is analyzed HNF-3553, Volume 3, Annex B Section B.3.4.2.5, "Multi-Canister Overpack Thermal Runaway Reaction." Preliminary thermal analyses performed for an MCO containing KOP material are documented 
in PRC-STP-00187, Sludge Treatment Project KOP Disposition Thermal and Gas Analysis for the Cold Vacuum Drying Facility (OCRWM). The analyses demonstrate the thermal stability of the KOP material during vacuum drying at the CVDF.

Thermal runaway reactions at the CSB are addressed in HNF-3553, Volume 2, Annex A, Canister Storage Building Final Safety Analysis Report. As discussed in Section A3.4.2.5, "Thermal Runaway Reactions Inside the Multi-Canister Overpack," thermal runaway reactions caused by fuel reacting with water were found to be not credible due to the limited quantity of free and chemically-bound water.

Initial conditions assumed in thermal analyses that must be protected include the quantity of KOP material in an MCO basket, the total quantity of KOP material in an MCO, the KOP material particle size, the total quantity of chemically-bound water in an $\mathrm{MCO}$, and the use of Copper Inserts. These assumptions are protected by a combination of engineered controls and administrative controls as indicated in Tables 4-3 and 4-4.

Table 4-3. MCO Thermal Runaway Engineered Controls

\begin{tabular}{|c|c|c|c|}
\hline $\begin{array}{c}\text { Item } \\
\text { No. }\end{array}$ & Safety Function & Safety Significant SSCs & Functional Requirements \\
\hline 1 & $\begin{array}{l}\text { Prevent an } \mathrm{MCO} \\
\text { thermal runaway by } \\
\text { protecting assumed } \\
\text { initial conditions } \\
\text { regarding the KOP } \\
\text { material particle size }\end{array}$ & Size Separations Table screen & $\begin{array}{l}\text { The Size Separations Table screen shall be } \\
\text { sized such that KOP material remaining on the } \\
\text { screen after washing has a Sauter mean } \\
\text { diameter } \geq 600 \mu \mathrm{m} \text {. }\end{array}$ \\
\hline 2 & $\begin{array}{l}\text { Prevent an } \mathrm{MCO} \\
\text { thermal runaway by } \\
\text { protecting assumed } \\
\text { initial conditions } \\
\text { regarding the } \\
\text { quantity of material } \\
\text { in an MCO basket }\end{array}$ & $\begin{array}{l}\text { - Verification Container } \\
\text { - Verification Container } \\
\text { weight measurement } \\
\text { instrumentation }\end{array}$ & $\begin{array}{l}\text { 1. The Verification Container shall indicate } \\
\text { the volume of KOP material in the } \\
\text { container with a to-be-determined accuracy } \\
\text { and precision. } \\
\text { 2. The Verification Container weight } \\
\text { measurement instrumentation shall } \\
\text { indicated the mass of the KOP material with } \\
\text { a to-be-determined accuracy and precision. } \\
\text { Note: The accuracy and precision functional } \\
\text { requirements for the Verification Container } \\
\text { volume and mass measurements will be } \\
\text { quantified during preliminary and final design. } \\
\text { Note: The total volume and mass of the KOP } \\
\text { material in an MCO is used to verify } \\
\text { compliance with limits for chemically-bound } \\
\text { water. }\end{array}$ \\
\hline
\end{tabular}


PRC-STP-00206 REV 0

Table 4-3. MCO Thermal Runaway Engineered Controls

\begin{tabular}{|c|l|l|l|}
\hline $\begin{array}{c}\text { Item } \\
\text { No. }\end{array}$ & Safety Function & Safety Significant SSCs & \multicolumn{1}{c|}{ Functional Requirements } \\
\hline 3 & $\begin{array}{l}\text { Prevent an MCO } \\
\text { thermal runaway by } \\
\text { protecting assumed } \\
\text { initial conditions } \\
\text { regarding the Copper } \\
\text { Inserts }\end{array}$ & Copper Inserts & $\begin{array}{l}\text { 1. The geometry of the Copper Inserts shall be } \\
\text { as shown on drawing KOP-CDR-SK-710 } \\
\text { (see Appendix A, Figures A-5 and A-6). } \\
\text { 2. The physical and thermal properties of the } \\
\text { Copper Inserts shall be to-be-determined. } \\
\text { The bottom of the Copper Inserts shall be } \\
\text { screened to retain KOP material greater } \\
\text { than } 500 \mu \text { in size. } \\
\text { Note: The physical and thermal properties of } \\
\text { the Copper Inserts will be based upon } \\
\text { assumptions in thermal and gas analyses to be } \\
\text { performed during preliminary and final design. }\end{array}$ \\
\hline
\end{tabular}

Table 4-4. MCO Thermal Runaway Administrative Controls

\begin{tabular}{|c|c|c|c|}
\hline $\begin{array}{c}\text { Item } \\
\text { No. }\end{array}$ & Safety Function & Administrative Control & Remarks \\
\hline 1 & $\begin{array}{l}\text { Prevent an MCO thermal } \\
\text { runaway by protecting } \\
\text { thermal analysis assumptions }\end{array}$ & $\begin{array}{l}\text { 1. Size Separation Table } \\
\text { operational controls } \\
\text { 2. The chemically-bound } \\
\text { water in an MCO shall not } \\
\text { exceed } 4.64 \mathrm{~kg} \text {. } \\
\text { 3. The maximum quantity of } \\
\text { KOP material in a Copper } \\
\text { Insert shall be } \\
\text { to-be-determined. } \\
\text { 4he maximum total } \\
\text { quantity of KOP material in } \\
\text { an MCO shall be } \\
\text { to-be-determined. } \\
\text { 5. An MCO basket containing } \\
\text { KOP material shall not be } \\
\text { loaded in the bottom-most } \\
\text { position of an MCO. }\end{array}$ & $\begin{array}{l}\text { The Size Separations Table operational } \\
\text { controls work in conjunction with the } \\
\text { safety-significant Size Separations } \\
\text { Table screen to ensure that the KOP } \\
\text { material remaining on the screen after } \\
\text { washing has a Sauter mean diameter } \\
\geq 600 \mu \mathrm{m} \text {. } \\
\text { The mass of chemically-bound water is } \\
\text { a function of the total quantity and } \\
\text { average density of the KOP material in } \\
\text { the MCO. } \\
\text { The maximum quantity of KOP } \\
\text { material in a Copper Insert, and the } \\
\text { maximum total quantity of KOP } \\
\text { material in an MCO will be } \\
\text { determined during preliminary and } \\
\text { final design. }\end{array}$ \\
\hline
\end{tabular}

\subsubsection{Multi-Canister Overpack Internal Hydrogen Deflagration}

The bounding MCO internal hydrogen deflagration design basis accident is analyzed HNF-3553, Volume 3, Annex B Section B.3.4.2.4, "Multi-Canister Overpack Internal Hydrogen 
Deflagration." Hydrogen deflagrations are also analyzed in HNF-3335, Annex A, Volume 2, Canister Storage Building Final Safety Analysis Report, and in HNF-SD-TP-SARP-017, Safety Analysis Report for Packaging (Onsite) Multi-Canister Overpack Cask. The rate at which hydrogen is produced is a function of the rate at which uranium metal in the KOP material is oxidized, which in turn is a function of uranium metal surface area as defined by the mass and particle size of the uranium metal. The consequences of an internal hydrogen deflagration are a function of the quantity of uranium oxide in an MCO. There is also a product specification for limiting the volume of organic material in an MCO. Therefore, the initial conditions assumed in the analyses that must be protected include the total quantity of KOP material in an $\mathrm{MCO}$, the KOP material particle size and density, the use of Copper Inserts, and the quantity of organic material. These assumptions are protected by a combination of engineered controls and administrative controls as indicated in Tables 4-3 and 4-4.

Table 4-5. MCO Internal Hydrogen Deflagration Engineered Controls

\begin{tabular}{|c|c|c|c|}
\hline $\begin{array}{c}\text { Item } \\
\text { No. }\end{array}$ & Safety Function & Safety Significant SSCs & Functional Requirements \\
\hline 1 & $\begin{array}{l}\text { Prevent an } \mathrm{MCO} \\
\text { internal hydrogen } \\
\text { deflagration by } \\
\text { protecting assumed } \\
\text { initial conditions } \\
\text { regarding the KOP } \\
\text { material particle size }\end{array}$ & Size Separations Table screen & $\begin{array}{l}\text { The Size Separations Table screen shall be } \\
\text { sized such that KOP material remaining on the } \\
\text { screen after washing has a Sauter mean } \\
\text { diameter } \geq 600 \mu \mathrm{m} \text {. } \\
\text { Note: The particle size of the material affects } \\
\text { the surface area which in turn affects the } \\
\text { reaction rate. }\end{array}$ \\
\hline 2 & $\begin{array}{l}\text { Prevent an MCO } \\
\text { internal hydrogen } \\
\text { deflagration by } \\
\text { protecting assumed } \\
\text { initial conditions } \\
\text { regarding the } \\
\text { quantity and density } \\
\text { of the KOP material } \\
\text { in an MCO basket }\end{array}$ & $\begin{array}{l}\text { - Verification Container } \\
\text { - Verification Container } \\
\text { weight measurement } \\
\text { instrumentation }\end{array}$ & $\begin{array}{l}\text { 1. The Verification Container shall indicate } \\
\text { the volume of KOP material in the } \\
\text { container with a to-be-determined accuracy } \\
\text { and precision. } \\
\text { 2. The Verification Container weight } \\
\text { measurement instrumentation shall } \\
\text { indicated the mass of the KOP material with } \\
\text { a to-be-determined accuracy and precision. } \\
\text { Note: The accuracy and precision functional } \\
\text { requirements for the Verification Container } \\
\text { volume and mass measurements will be } \\
\text { quantified during preliminary and final design. }\end{array}$ \\
\hline
\end{tabular}


Table 4-5. MCO Internal Hydrogen Deflagration Engineered Controls

\begin{tabular}{|c|l|l|l|}
\hline $\begin{array}{c}\text { Item } \\
\text { No. }\end{array}$ & \multicolumn{1}{|c|}{ Safety Function } & Safety Significant SSCs & \multicolumn{1}{c|}{ Functional Requirements } \\
\hline 3 & $\begin{array}{l}\text { Prevent an MCO } \\
\text { internal hydrogen } \\
\text { deflagration by } \\
\text { protecting assumed } \\
\text { initial conditions } \\
\text { regarding the Copper } \\
\text { Inserts }\end{array}$ & Copper Inserts & $\begin{array}{l}\text { 1. The geometry of the Copper Inserts shall be } \\
\text { as shown on drawing KOP-CDR-SK-710 } \\
\text { (see Appendix A, Figures A-5 and A-6). } \\
\text { 2. The physical and thermal properties of the } \\
\text { Copper Inserts shall be to-be-determined. } \\
\text { The bottom of the Copper Inserts shall be } \\
\text { screened to retain KOP material greater } \\
\text { than } 500 \mu \text { in size. } \\
\text { Note: The physical and thermal properties of } \\
\text { the Copper Inserts will be based upon } \\
\text { assumptions in thermal and gas analyses to be } \\
\text { performed during preliminary and final design. }\end{array}$ \\
\hline
\end{tabular}

Table 4-6. MCO Internal Hydrogen Deflagration Administrative Controls

\begin{tabular}{|c|l|l|l|}
\hline $\begin{array}{c}\text { Item } \\
\text { No. }\end{array}$ & \multicolumn{1}{|c|}{ Safety Function } & \multicolumn{1}{|c|}{ Administrative Control } & \multicolumn{1}{c|}{ Remarks } \\
\hline 1 & $\begin{array}{l}\text { Prevent an MCO } \\
\text { internal hydrogen } \\
\text { deflagration by } \\
\text { protecting accident } \\
\text { analysis assumptions }\end{array}$ & $\begin{array}{l}\text { 1.Size Separation Table operational } \\
\text { controls } \\
\text { 2.An MCO basket containing KOP } \\
\text { material shall not be loaded in the } \\
\text { bottom-most position of an MCO. } \\
\text { 3. Organic material in the KOP } \\
\text { material that is identified by visual } \\
\text { inspection shall not be loaded into } \\
\text { a Verification Container with the } \\
\text { exception of carbon materials, such } \\
\text { as grafoil, that do not result in } \\
\text { radiolytic gas production. } \\
\text { 4.Prior to the addition of KOP } \\
\text { material, Verification Containers } \\
\text { and Copper Inserts will be } \\
\text { inspected to identify and remove } \\
\text { foreign materials. }\end{array}$ & $\begin{array}{l}\text { The Size Separations Table operational } \\
\text { controls work in conjunction with the } \\
\text { safety-significant Size Separations } \\
\text { Table screen to ensure that the KOP } \\
\text { material remaining on the screen after } \\
\text { washing has a Sauter mean diameter } \\
\geq 600 \text { mm. }\end{array}$ \\
$\begin{array}{l}\text { Administrative Control \#3 is based } \\
\text { HNF-SD-SNF-TSR-001, K Basin } \\
\text { Technical Safety Requirements, } \\
\text { Section 5.9.2.3, "Multi-Canister } \\
\text { Overpack Basket Loading Controls." } \\
\text { During preliminary design, alternate } \\
\text { means of removing organic material } \\
\text { (e.g., use of the low-density retrieval } \\
\text { wand) will be evaluated. } \\
\text { The current product specification for } \\
\text { MCOs allow a total of one pound of } \\
\text { organic material. }\end{array}$ \\
\hline
\end{tabular}

\subsubsection{Multi-Canister Overpack Overpressurization}

The bounding MCO overpressurization design basis accident is analyzed HNF-3553, Volume 3, Annex B Section B.3.4.2.6, "Multi-Canister Overpack Ovepressurization." An 
overpressurization is also analyzed in HNF-SD-TP-SARP-017. Overpressurization accidents are primarily caused by the generation of hydrogen gas from the oxidation of uranium metal. Therefore, the same initial conditions assumed in the hydrogen deflagration analyses must be protected for the overpressurization analyses. Tables 4-7 and 4-8 repeat the controls identified in Tables 4-5 and 4-6. The safety function of the controls is revised to reflect prevention of the overpressurization DBA.

Table 4-7. MCO Overpressurization Engineered Controls

\begin{tabular}{|c|c|c|c|}
\hline $\begin{array}{c}\text { Item } \\
\text { No. }\end{array}$ & Safety Function & Safety Significant SSCs & Functional Requirements \\
\hline 1 & $\begin{array}{l}\text { Prevent an MCO } \\
\text { overpressurization by } \\
\text { protecting assumed } \\
\text { initial conditions } \\
\text { regarding the KOP } \\
\text { material particle size }\end{array}$ & Size Separations Table screen & $\begin{array}{l}\text { The Size Separations Table screen shall be } \\
\text { sized such that KOP material remaining on the } \\
\text { screen after washing has a Sauter mean } \\
\text { diameter } \geq 600 \mu \mathrm{m} \text {. } \\
\text { Note: The particle size of the material affects } \\
\text { the surface area which in turn affects the } \\
\text { reaction rate. }\end{array}$ \\
\hline 2 & $\begin{array}{l}\text { Prevent an MCO } \\
\text { overpressurization by } \\
\text { protecting assumed } \\
\text { initial conditions } \\
\text { regarding the } \\
\text { quantity and density } \\
\text { of the KOP material } \\
\text { in an MCO basket }\end{array}$ & $\begin{array}{l}\text { - Verification Container } \\
\text { - Verification Container } \\
\text { weight measurement } \\
\text { instrumentation }\end{array}$ & $\begin{array}{l}\text { 1. The Verification Container shall indicate } \\
\text { the volume of KOP material in the } \\
\text { container with a to-be-determined accuracy } \\
\text { and precision. } \\
\text { 2. The Verification Container weight } \\
\text { measurement instrumentation shall } \\
\text { indicated the mass of the KOP material with } \\
\text { a to-be-determined accuracy and precision. } \\
\text { Note: The accuracy and precision functional } \\
\text { requirements for the Verification Container } \\
\text { volume and mass measurements will be } \\
\text { quantified during preliminary and final design. } \\
\text { Note: The total volume and mass of the KOP } \\
\text { material in an MCO is used to verify } \\
\text { compliance with limits for chemically-bound } \\
\text { water. }\end{array}$ \\
\hline
\end{tabular}


PRC-STP-00206 REV 0

Table 4-7. MCO Overpressurization Engineered Controls

\begin{tabular}{|c|l|l|l|}
\hline $\begin{array}{c}\text { Item } \\
\text { No. }\end{array}$ & \multicolumn{1}{|c|}{ Safety Function } & Safety Significant SSCs & \multicolumn{1}{c|}{ Functional Requirements } \\
\hline 3 & $\begin{array}{l}\text { Prevent an MCO } \\
\text { overpressurization by } \\
\text { protecting assumed } \\
\text { initial conditions } \\
\text { regarding the Copper } \\
\text { Inserts }\end{array}$ & Copper Inserts & $\begin{array}{l}\text { 1. The geometry of the Copper Inserts shall be } \\
\text { as shown on drawing KOP-CDR-SK-710 } \\
\text { (see Appendix A, Figures A-5 and A-6). } \\
\text { 2. The physical and thermal properties of the } \\
\text { Copper Inserts shall be to-be-determined. } \\
\text { The bottom of the Copper Inserts shall be } \\
\text { screened to retain KOP material greater } \\
\text { than 500 } \mu \text { in size. } \\
\text { Note: The physical and thermal properties of } \\
\text { the Copper Inserts will be based upon } \\
\text { assumptions in thermal and gas analyses to be } \\
\text { performed during preliminary and final design. }\end{array}$ \\
\hline
\end{tabular}

Table 4-8. MCO Overpressurization Administrative Controls

\begin{tabular}{|c|c|c|c|}
\hline $\begin{array}{c}\text { Item } \\
\text { No. }\end{array}$ & Safety Function & Administrative Control & Remarks \\
\hline 1 & $\begin{array}{l}\text { Prevent an MCO } \\
\text { overpressurization by } \\
\text { protecting accident } \\
\text { analysis assumptions }\end{array}$ & $\begin{array}{l}\text { 1. Size Separation Table operational } \\
\text { controls } \\
\text { 2. The chemically-bound water in an } \\
\text { MCO shall not exceed } 4.64 \mathrm{~kg} \text {. } \\
\text { 3. An MCO basket containing KOP } \\
\text { material shall not be loaded in the } \\
\text { bottom-most position of an MCO. } \\
\text { 4. Organic material in the KOP } \\
\text { material that is identified by visual } \\
\text { inspection shall not be loaded into } \\
\text { a Verification Container with the } \\
\text { exception of carbon materials, } \\
\text { such as grafoil, that do not result } \\
\text { in radiolytic gas production. } \\
\text { 5. Prior to the addition of KOP } \\
\text { material, Verification Containers } \\
\text { and Copper Inserts will be } \\
\text { inspected to identify and remove } \\
\text { foreign materials. }\end{array}$ & $\begin{array}{l}\text { The Size Separations Table operational } \\
\text { controls work in conjunction with the } \\
\text { safety-significant Size Separations } \\
\text { Table screen to ensure that the KOP } \\
\text { material remaining on the screen after } \\
\text { washing has a Sauter mean diameter } \\
\geq 600 \mu \mathrm{m} \text {. } \\
\text { The mass of chemically-bound water is } \\
\text { a function of the total quantity and } \\
\text { average density of the KOP material in } \\
\text { the MCO. } \\
\text { Administrative Control \#4 is based } \\
\text { HNF-SD-SNF-TSR-001, K Basin } \\
\text { Technical Safety Requirements, } \\
\text { Section } 5.9 .2 .3 \text {, "Multi-Canister } \\
\text { Overpack Basket Loading Controls." } \\
\text { During preliminary design, alternate } \\
\text { means of removing organic material } \\
\text { (e.g., use of the low-density retrieval } \\
\text { wand) will be evaluated. }\end{array}$ \\
\hline
\end{tabular}




\subsubsection{Nuclear Criticality Safety}

The KOP material contains more than a minimum critical mass of fissile material such that an inadvertent nuclear criticality must be addressed. A criticality safety evaluation was performed to specifically address criticality safety requirements that will or may be necessary to support planned KOP Disposition Project activities associated. As documented in PRC-STP-00219, Sludge Treatment Project KOP Disposition Conceptual Design Criticality Safety Evaluation, fissile mass loading limits for the MCOs will probably be required to support MCO shipment and may be required for $\mathrm{MCO}$ loading. Consequently, scales used to determine the mass of fissile material loaded into an MCO basket may be safety significant for criticality safety. The scale used to weigh the Verification Container and determine the mass of KOP material has been classified as safety significant to protect initial conditions assumed in the thermal and gas analyses. If required by additional criticality studies performed during preliminary and detailed design, the safety function of the scale will be revised to include prevention of criticality accidents. 


\subsection{REFERENCES}

DOE-STD-1189-2008, 2008, Integration of Safety Into the Design Process, U.S. Department of Energy, Washington D.C.

DOE-STD-3009-94, 2006, Preparation Guide for U.S. Department of Energy Nonreactor Nuclear Facility Documented Safety Analyses, Change Notice 3, U.S. Department of Energy, Washington D.C.

KBC-38156, 2008, Conceptual Feasibility Report for KOP Accelerated Disposition, Rev. 0, Fluor Hanford, Inc., Richland, Washington.

HNF-2229, Fuel Retrieval Sub-Project Design Analysis Report for Safety Class In-Pool Equipment-Volumes I, II, and III, Rev. 0B, Fluor Hanford, Inc., Richland, Washington.

HNF-3335, 2009, Annex A, Volume 2, Canister Storage Building Final Safety Analysis Report, Rev. 6, CH2M HILL Plateau Remediation Company, Richland, Washington.

HNF-3553, 2009, Volume 3, Annex B, Cold Vacuum Drying Facility Final Safety Analysis Report, Rev. 6, CH2M HILL Plateau Remediation Company, Richland, Washington.

HNF-3960, 2009, K Basins Hazard Analysis, Rev. 7, CH2M HILL Plateau Remediation Company, Richland, Washington.

HNF-SD-TP-SARP-017, 2009, Safety Analysis Report for Packaging (Onsite) Multi-Canister Overpack Cask, Rev. 3F, CH2M HILL Plateau Remediation Company, Richland, Washington.

HNF-SD-SNF-TSR-001, 2009, K Basin Technical Safety Requirements, Rev. 10, CH2M HILL Plateau Remediation Company, Richland, Washington.

HNF-SD-WM-SAR-062, 2009, KW Basin Final Safety Analysis Report, Rev 14D, CH2M HILL Plateau Remediation Company, Richland, Washington.

PRC-MP-QA-599, 2009, Quality Assurance Program, Rev. 0, Change 2, CH2M HILL Plateau Remediation Company, Richland, Washington.

PRC-PRO-EN-286, 2009, Testing of Equipment and Systems, Rev. 0, Change 1, CH2M HILL Plateau Remediation Company, Richland, Washington.

PRC-PRO-NS-062,2009, Unreviewed Safety Question Process, Rev. 0, Change 0, CH2M HILL Plateau Remediation Company, Richland, Washington.

PRC-STP-00098, 2009, Knock-Out Pot Disposition Project Conceptual Design Hazard Analysis, Rev. 0, CH2M HILL Plateau Remediation Company, Richland, Washington.

PRC-STP-00127, 2009, Basket Washing and KOP Material at Risk Discussion, Rev. 0, CH2M HILL Plateau Remediation Company, Richland, Washington.

PRC-STP-00187, 2010, Sludge Treatment Project KOP Disposition Thermal and Gas Analysis for the Cold Vacuum Drying Facility, Rev. 0, CH2M HILL Plateau Remediation Company, Richland, Washington. 
PRC-STP-00219, 2010, Sludge Treatment Project KOP Disposition Conceptual Design Criticality Safety Evaluation Rev. 0, CH2M HILL Plateau Remediation Company, Richland, Washington.

PRC-STP-CN-N-00167, 2009, Knock-Out Pot Disposition Sub-Project Canister Over Lift Accident Analysis, Rev. 0, CH2M HILL Plateau Remediation Company, Richland, Washington. 
PRC-STP-00206 REV 0

APPENDIX A

KOP DISPOSITION PROJECT CONCEPTUAL DESIGN

ENGINEERING DRAWINGS 


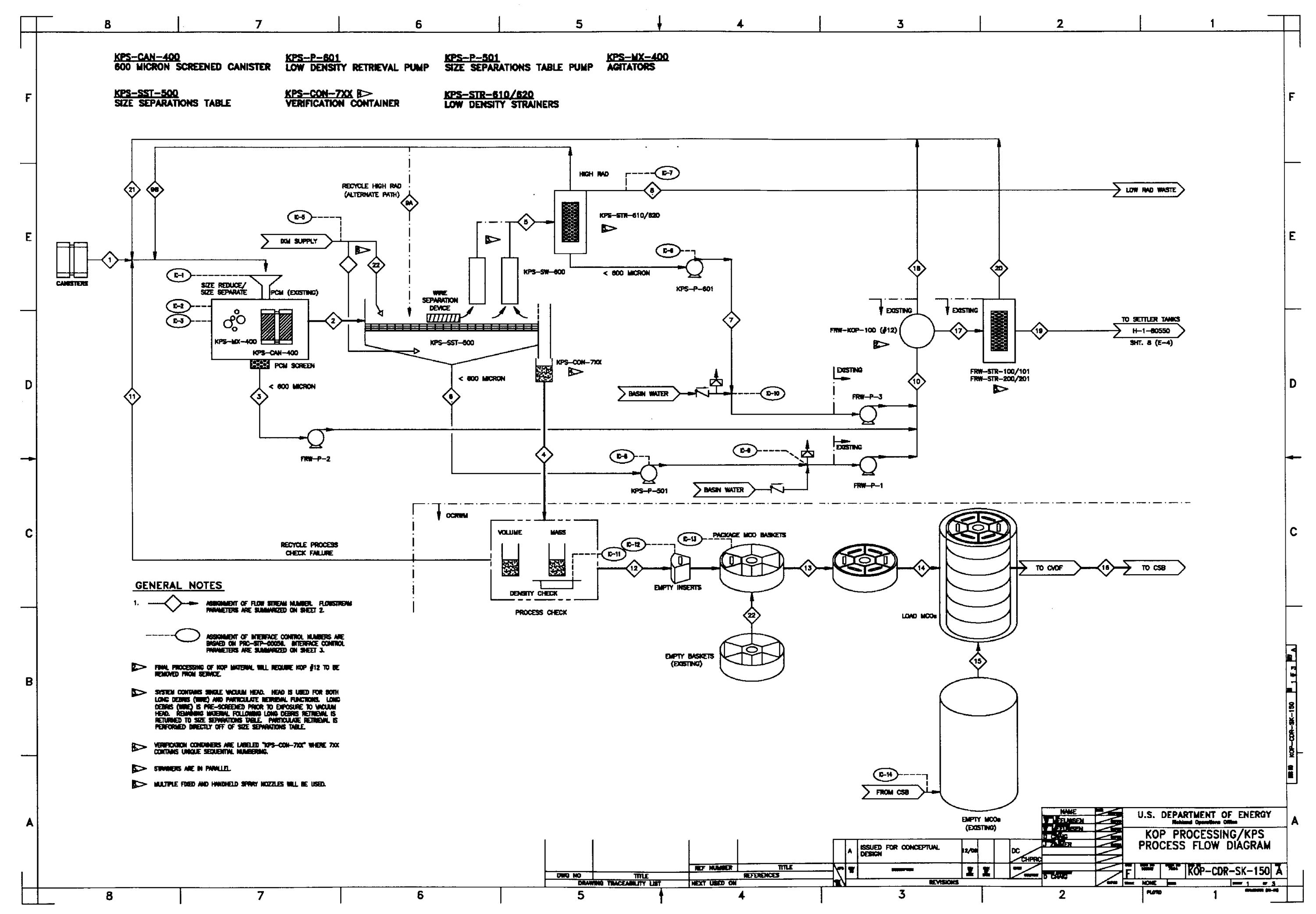


Figure A-2. Piping \& Instrumentation Diagram Legends, Notes, and Key (KOP-CDR-SK-160, Rev. A, Sheet 1 of 1)

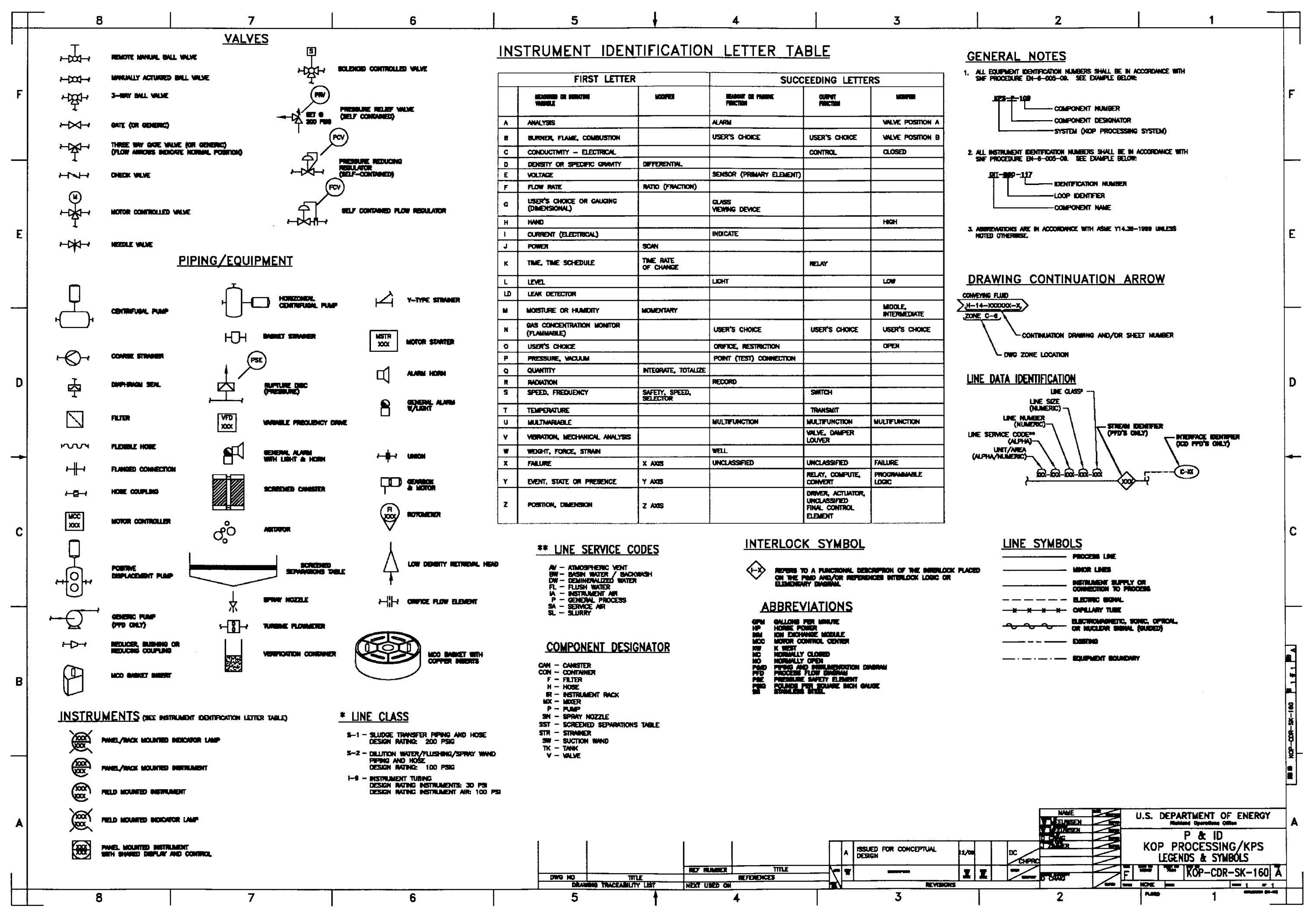


Figure A-3. Piping \& Instrumentation Diagram (KOP-CDR-SK-170, Rev. A, Sheet 1 of 2)

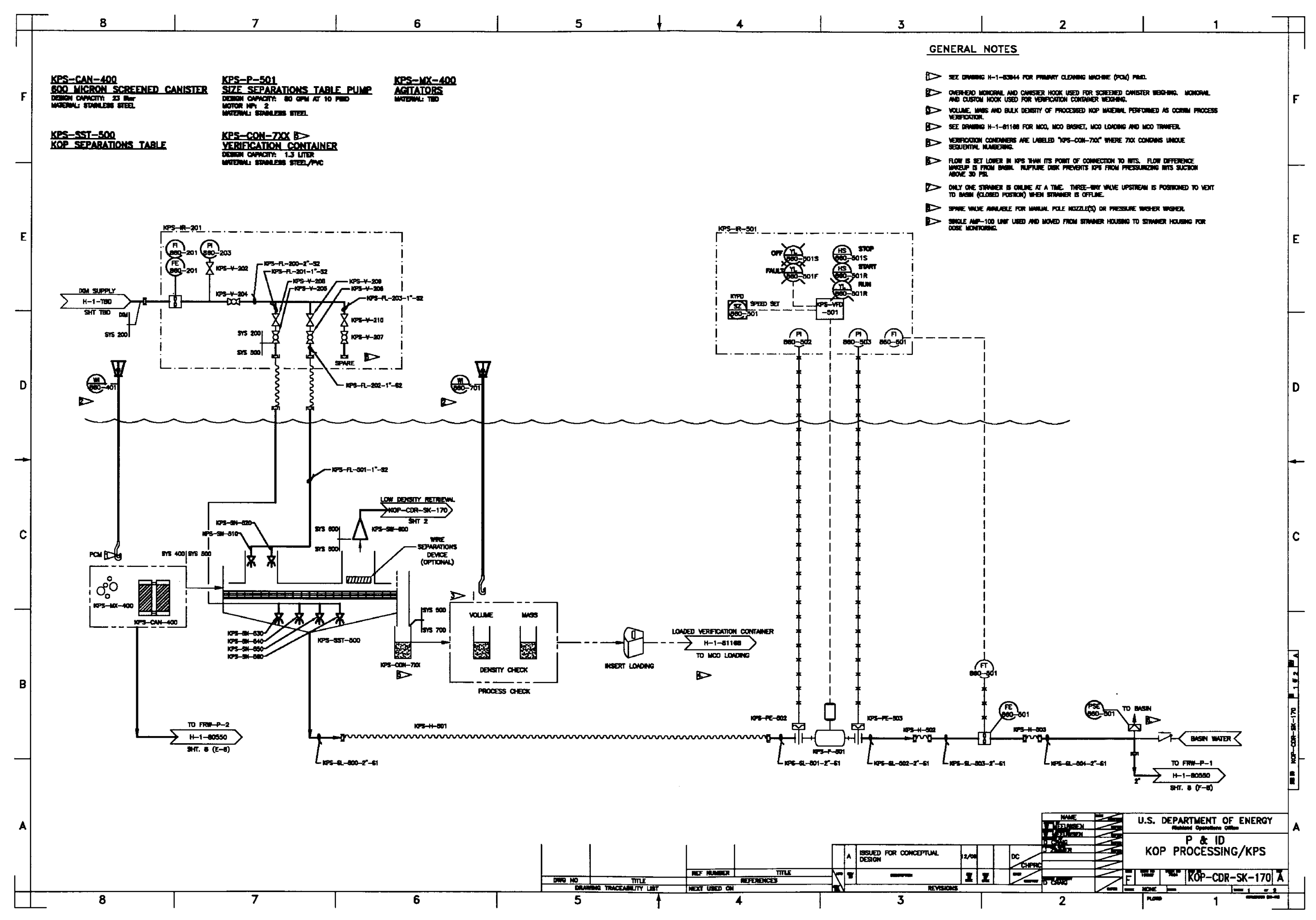




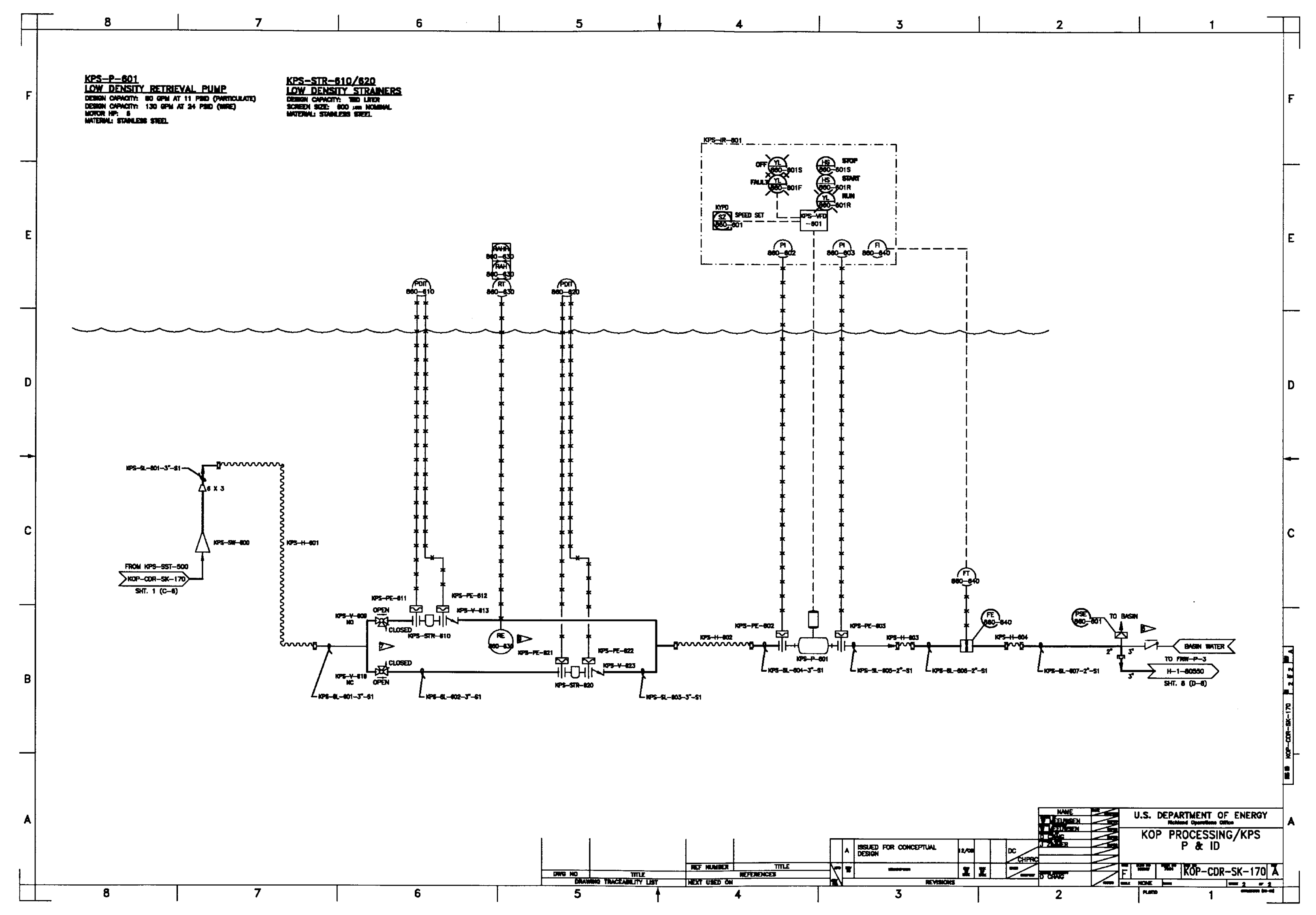


Figure A-5. KOP MCO Basket Insert (KOP-CDR-SK-710, Rev. A, Sheet 1 of 2)

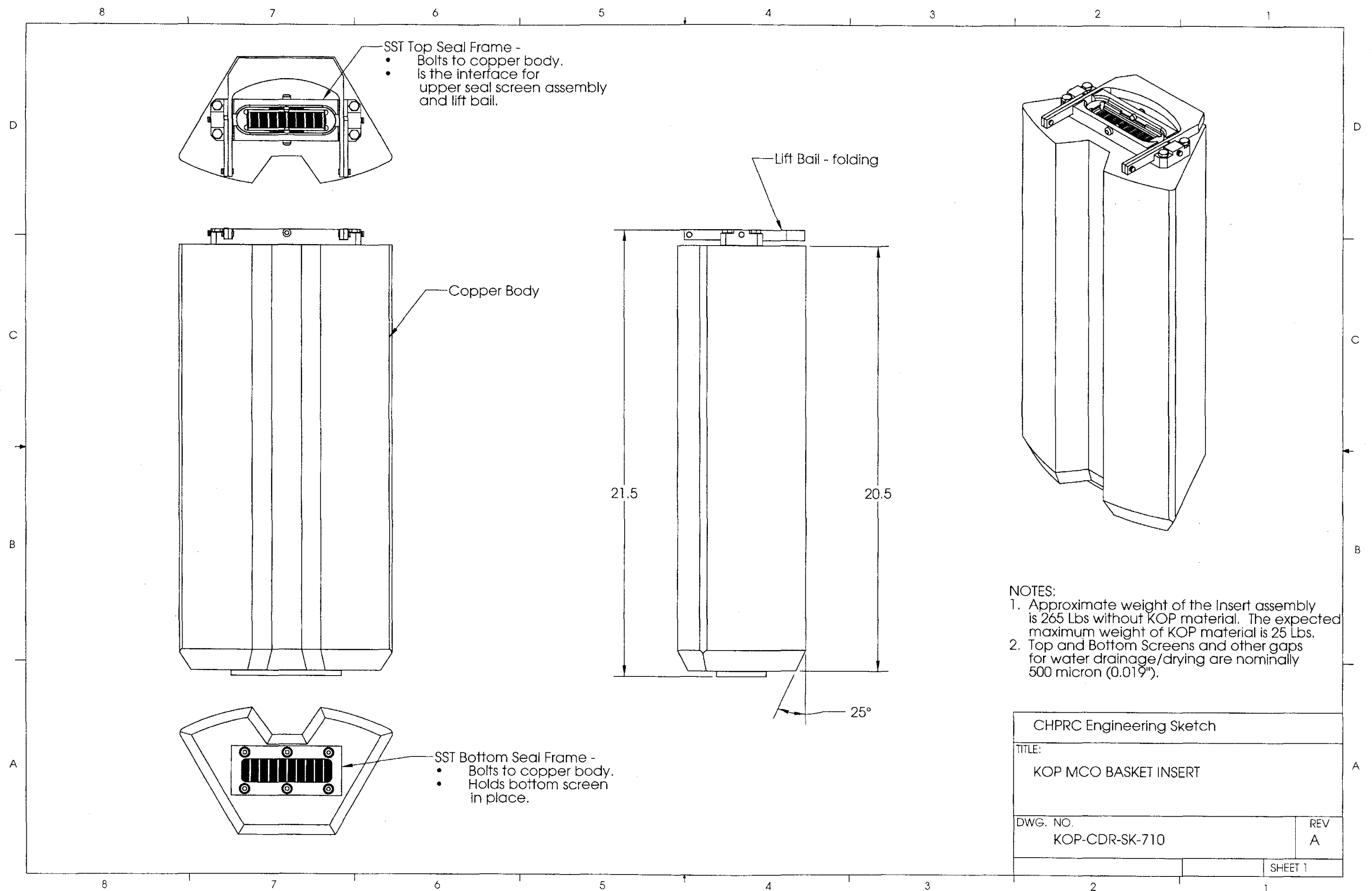


Figure A-6. KOP MCO Basket Insert (KOP-CDR-SK-710, Rev. A, Sheet 2 of 2)

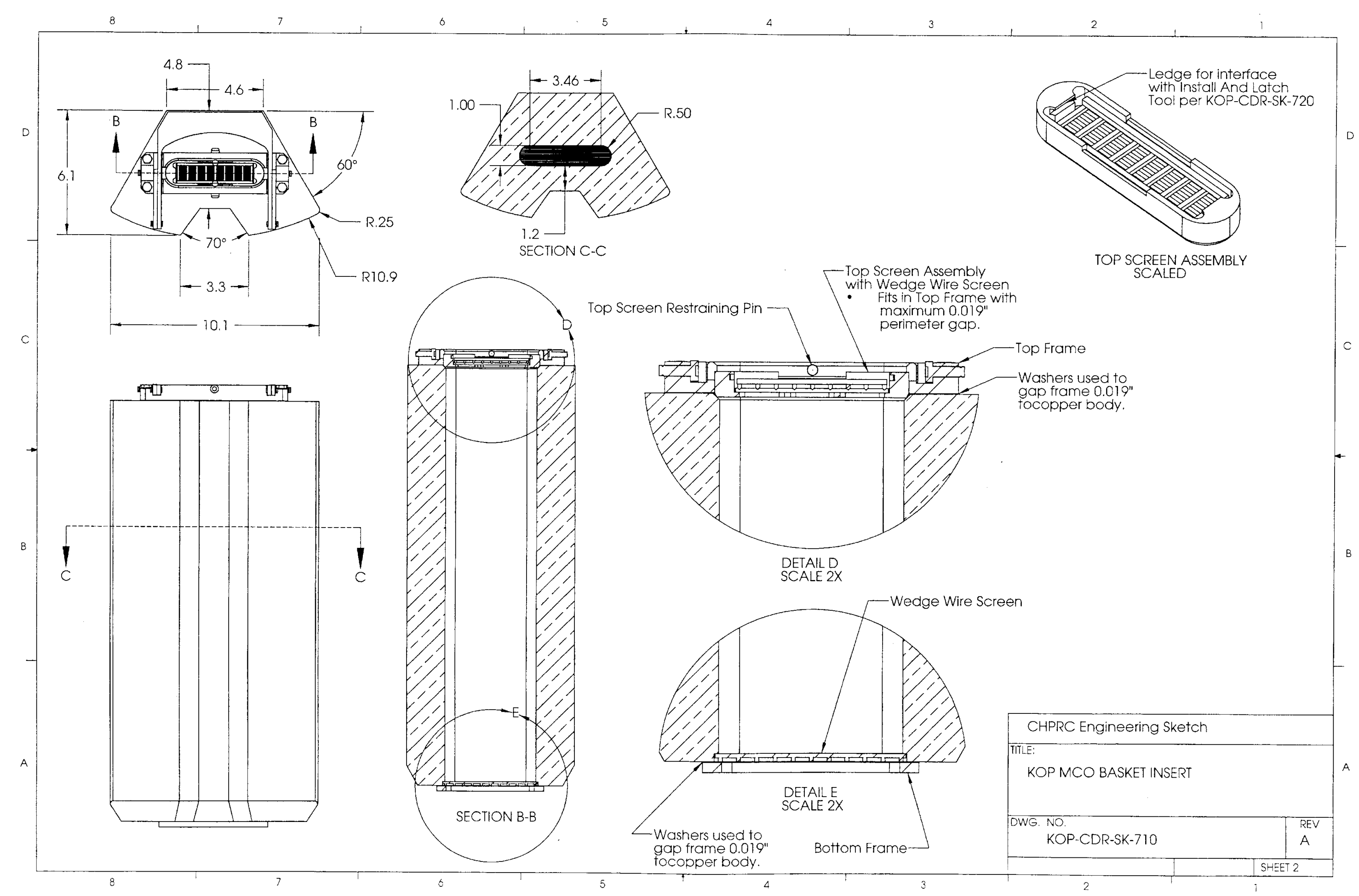




\section{APPENDIX B}

CONTROL DECISION MEETING PARTICIPANTS 
APPENDIX B

\section{CONTROL DECISION MEETING PARTICIPANTS}

Table B-1. Control Decision Meeting Participants

February 1, 2010

\begin{tabular}{|l|l|}
\hline \multicolumn{1}{|c|}{ Name } & \multicolumn{1}{c|}{ Organization } \\
\hline \multicolumn{2}{|c|}{ Control Decision Team } \\
\hline Craig Carro & STP Nuclear Safety - Facilitator \\
\hline Ralph Crowe & STP Nuclear Safety \\
\hline Jim Mathews & Operations \\
\hline Greg Bergquist & 100 K Area Engineering \\
\hline Jim Sloughter & STP Process Engineering \\
\hline Lindsay Nelsen & STP Radiological Control \\
\hline Daren Schwartz & 100 K Area Operational Safety and Health \\
\hline & Additional Attendees \\
\hline Gary Franz & STP Nuclear Safety \\
\hline Bill Meeuwsen & STP Engineering \\
\hline
\end{tabular}


PRC-STP-00206 REV 0

\section{APPENDIX C \\ CONTROL ALLOCATION TABLES}


Table C-1. Thermal Runaway Control Decision

\begin{tabular}{|c|c|c|c|c|c|c|c|}
\hline \multirow[b]{2}{*}{ Node } & \multirow{2}{*}{ What-If? } & \multirow{2}{*}{ Cause } & \multirow[b]{2}{*}{ Consequence } & \multicolumn{2}{|c|}{ Candidate Controls } & \multirow{2}{*}{ Selected Controls } & \multirow[b]{2}{*}{ Remarks } \\
\hline & & & & Safety SSC Options & $\begin{array}{c}\text { Administrative Control } \\
\text { Options }\end{array}$ & & \\
\hline 1.10 & $\begin{array}{l}\text { What if the screened } \\
\text { canister openings } \\
\text { are smaller than } \\
600 \mu \mathrm{m} \text { ? }\end{array}$ & Manufacturing error & $\begin{array}{l}\text { If the openings were smaller } \\
\text { than } 600 \mu \mathrm{m} \text {, then material } \\
<600 \mu \mathrm{m} \text { would be retained and } \\
\text { subsequently transferred to the } \\
\text { Screened Separations Table. If } \\
\text { not removed at the Screened } \\
\text { Separations Table, the }<600 \mu \mathrm{m} \\
\text { material would be loaded into a } \\
\text { Verification Container and } \\
\text { eventually into an MCO. }\end{array}$ & $\begin{array}{l}\text { - Screened canister safety } \\
\text { classification } \\
\text { - Screened Separations } \\
\text { Table safety classification }\end{array}$ & $\begin{array}{l}\text { - Quality Assurance } \\
\text { Program } \\
\text { - Administrative Control TSR } \\
\text { for Screened Separations } \\
\text { Table activities }\end{array}$ & $\begin{array}{l}\text { Preventive Engineered: } \\
\text { - Screened Separations Table safety } \\
\text { classification } \\
\text { Preventive Administrative: } \\
\text { - Quality Assurance Program } \\
\text { - Administrative Control TSR for } \\
\text { Screened Separations Table activities } \\
\text { Mitigative Engineered: } \\
\text { None } \\
\text { Mitigative Administrative: } \\
\text { None }\end{array}$ & $\begin{array}{l}\text { Both the screened canister and } \\
\text { the Screened Separations Table } \\
\text { function to remove particles } \\
<600 \mu \mathrm{m} \text {. The control decision } \\
\text { team chose to credit the } \\
\text { Screened Separations Table } \\
\text { because it is a closer to a } \\
\text { passive engineered system than } \\
\text { is the PCM. }\end{array}$ \\
\hline 1.12 & $\begin{array}{l}\text { What if the scale } \\
\text { erroneously } \\
\text { indicates that the } \\
\text { screened canister is } \\
\text { no longer losing } \\
\text { mass? }\end{array}$ & $\begin{array}{l}\text { - Operator error } \\
\text { - Equipment failure } \\
\text { - Calibration error }\end{array}$ & $\begin{array}{l}\text { If the scale erroneously } \\
\text { indicates that the mass of a } \\
\text { screened canister is no longer } \\
\text { decreasing, then additional } \\
\text { washing would not be } \\
\text { performed. Consequently, the } \\
\text { KOP material that is transferred } \\
\text { to the Screened Separations } \\
\text { Table would contain more } \\
\text { particles }<600 \mu \text { m in size than it } \\
\text { otherwise would. If not } \\
\text { removed at the Screened } \\
\text { Separations Table, the < } 600 \mu \mathrm{m} \\
\text { material would be loaded into a } \\
\text { Verification Container and } \\
\text { eventually into an MCO. }\end{array}$ & $\begin{array}{l}\text { - Scale safety classification } \\
\text { - Screened Separations } \\
\text { Table safety classification }\end{array}$ & $\begin{array}{l}\text { - Quality Assurance } \\
\text { Program } \\
\text { - Administrative Control TSR } \\
\text { for Screened Separations } \\
\text { Table activities }\end{array}$ & $\begin{array}{l}\text { Preventive Engineered: } \\
\text { - Screened Separations Table safety } \\
\text { classification } \\
\text { Preventive Administrative: } \\
\text { - Quality Assurance Program } \\
\text { - Administrative Control TSR for } \\
\text { Screened Separations Table activities } \\
\text { Mitigative Engineered: } \\
\text { None } \\
\text { Mitigative Administrative: } \\
\text { None }\end{array}$ & \\
\hline
\end{tabular}


Table C-1. Thermal Runaway Control Decisio

\begin{tabular}{|c|c|c|c|c|c|c|c|}
\hline \multirow{2}{*}{ Node } & \multirow{2}{*}{ What-If? } & \multirow{2}{*}{ Cause } & \multirow{2}{*}{ Consequence } & \multicolumn{2}{|c|}{ Candidate Controls } & \multirow{2}{*}{ Selected Controls } & \multirow[b]{2}{*}{ Remarks } \\
\hline & & & & Safety SSC Options & $\begin{array}{l}\text { Administrative Control } \\
\text { Options }\end{array}$ & & \\
\hline 1.17 & $\begin{array}{l}\text { What if the screened } \\
\text { canister becomes } \\
\text { plugged? }\end{array}$ & None specified & $\begin{array}{l}\text { If the screened canister } \\
\text { becomes plugged, then } \\
<600 \mu m \text { particles will not be } \\
\text { washed from the KOP material } \\
\text { in the PCM. Consequently, the } \\
\text { KOP material that is transferred } \\
\text { to the Screened Separations } \\
\text { Table would contain more } \\
\text { particles }<600 \mu m \text { in size than it } \\
\text { otherwise would. If not } \\
\text { removed at the Screened } \\
\text { Separations Table, the }<600 \mu m \\
\text { material would be loaded into a } \\
\text { Verification Container and } \\
\text { eventually into an MCO. }\end{array}$ & $\begin{array}{l}\text { Screened Separations Table } \\
\text { safety classification }\end{array}$ & $\begin{array}{l}\text { Administrative Control TSR } \\
\text { for Screened Separations } \\
\text { Table activities }\end{array}$ & $\begin{array}{l}\text { Preventive Engineered: } \\
\text { - Screened Separations Table safety } \\
\text { classification } \\
\text { Preventive Administrative: } \\
\text { - Administrative Control TSR for } \\
\text { Screened Separations Table activities } \\
\text { Mitigative Engineered: } \\
\text { None } \\
\text { Mitigative Administrative: } \\
\text { None }\end{array}$ & $\begin{array}{l}\text { The Administrative Control TSR } \\
\text { for Screened Separations Table } \\
\text { activities will require operators } \\
\text { to spread the material over the } \\
\text { surface of the screen using the } \\
\text { water sparger and/or manual } \\
\text { tools and to perform a visual } \\
\text { inspection. }\end{array}$ \\
\hline 2.11 & $\begin{array}{l}\text { What if the } \\
\text { Screened } \\
\text { Separations Table } \\
\text { pump fails to } \\
\text { operate? }\end{array}$ & $\begin{array}{l}\text { - Loss of power to } \\
\text { pump } \\
\text { - Mechanical failure }\end{array}$ & $\begin{array}{l}\text { If the Screened Separations } \\
\text { Table pump fails to operate, } \\
\text { then there will be no motive } \\
\text { force besides gravity to draw } \\
<600 \mu \mathrm{m} \text { particles through the } \\
\text { screen. Particles }<600 \mu \mathrm{m} \\
\text { could be loaded into the } \\
\text { Verification Containers. }\end{array}$ & None & $\begin{array}{l}\text { Administrative Control TSR } \\
\text { for Screened Separations } \\
\text { Table activities }\end{array}$ & $\begin{array}{l}\text { Preventive Engineered: } \\
\text { None } \\
\text { Preventive Administrative: } \\
\text { - Administrative Control TSR for } \\
\text { Screened Separations Table activities } \\
\text { Mitigative Engineered: } \\
\text { None } \\
\text { Mitigative Administrative: } \\
\text { None }\end{array}$ & $\begin{array}{l}\text { During the control decision } \\
\text { meeting, it was discussed that } \\
\text { the pump suction is not required } \\
\text { for }<600 \text { particles to pass } \\
\text { through the screen. The } \\
\text { function of the pump is to } \\
\text { provide the motive force to } \\
\text { transfer material that passes } \\
\text { through the screen to the IWTS } \\
\text { system. }\end{array}$ \\
\hline 2.20 & $\begin{array}{l}\text { What if the KOP } \\
\text { material is not } \\
\text { properly processed } \\
\text { on the screened } \\
\text { portion of the } \\
\text { Screened } \\
\text { Separations Table } \\
\text { (i.e., what if not } \\
\text { enough "laps" are } \\
\text { performed). }\end{array}$ & Operator error & $\begin{array}{l}\text { If the KOP is not properly } \\
\text { processed on the screened } \\
\text { portion of the table, then } \\
<600 \mu m \text { particles could be } \\
\text { loaded into a Verification } \\
\text { Container and eventually into an } \\
\text { MCO. }\end{array}$ & None & $\begin{array}{l}\text { Administrative Control TSR } \\
\text { for Screened Separations } \\
\text { Table activities }\end{array}$ & $\begin{array}{l}\text { Preventive Engineered: } \\
\text { None } \\
\text { Preventive Administrative: } \\
\text { - Administrative Control TSR for } \\
\text { Screened Separations Table activities } \\
\text { Mitigative Engineered: } \\
\text { None } \\
\text { Mitigative Administrative: } \\
\text { None }\end{array}$ & \\
\hline
\end{tabular}


Table C-1. Thermal Runaway Control Decision

\begin{tabular}{|c|c|c|c|c|c|c|c|}
\hline \multirow[b]{2}{*}{ Node } & \multirow[b]{2}{*}{ What-If? } & \multirow[b]{2}{*}{ Cause } & \multirow[b]{2}{*}{ Consequence } & \multicolumn{2}{|c|}{ Candidate Controls } & \multirow[b]{2}{*}{ Selected Controls } & \multirow[b]{2}{*}{ Remarks } \\
\hline & & & & Safety SSC Options & $\begin{array}{c}\text { Administrative Control } \\
\text { Options }\end{array}$ & & \\
\hline 2.21 & $\begin{array}{l}\text { What if the screened } \\
\text { portion of the } \\
\text { Screened } \\
\text { Separations Table } \\
\text { becomes plugged? }\end{array}$ & None specified & $\begin{array}{l}\text { If the screened portion of the } \\
\text { table plugs, then particles }<600 \\
\mu m \text { could be loaded into the } \\
\text { Verification Containers and } \\
\text { eventually into an } \mathrm{MCO} \text {. }\end{array}$ & None & $\begin{array}{l}\text { Administrative Control TSR } \\
\text { for Screened Separations } \\
\text { Table activities }\end{array}$ & $\begin{array}{l}\text { Preventive Engineered: } \\
\text { None } \\
\text { Preventive Administrative: } \\
\text { - Administrative Control TSR for } \\
\quad \text { Screened Separations Table activities } \\
\text { Mitigative Engineered: } \\
\text { None } \\
\text { Mitigative Administrative: } \\
\text { None }\end{array}$ & \\
\hline 2.22 & $\begin{array}{l}\text { What if the openings } \\
\text { of the screened } \\
\text { portion of the } \\
\text { Screened } \\
\text { Separations Table } \\
\text { are smaller than } \\
600 \mu \mathrm{m} \text { ? }\end{array}$ & Manufacturing error & $\begin{array}{l}\text { If the openings of the screened } \\
\text { portion of the table are smaller } \\
\text { than } 600 \mu \mathrm{m} \text {, then particles } \\
<600 \mu \mathrm{m} \text { could be loaded into } \\
\text { the Verification Containers and } \\
\text { eventually into an MCO. }\end{array}$ & $\begin{array}{l}\text { Screened separation table } \\
\text { safety classification }\end{array}$ & Quality Assurance Program & $\begin{array}{l}\text { Preventive Engineered: } \\
\text { - Screened Separations Table safety } \\
\text { classification } \\
\text { Preventive Administrative: } \\
\text { - Quality Assurance Program } \\
\text { Mitigative Engineered: } \\
\text { None } \\
\text { Mitigative Administrative: } \\
\text { None }\end{array}$ & \\
\hline 4.1 & $\begin{array}{l}\text { What if the Copper } \\
\text { Insert outer } \\
\text { dimensions are } \\
\text { smaller than } \\
\text { specified? }\end{array}$ & Manufacturing error & $\begin{array}{l}\text { Thermal Runaway: If the } \\
\text { Copper Insert outer dimensions } \\
\text { are smaller than specified, then } \\
\text { the mass of copper will be less } \\
\text { than analyzed in the thermal } \\
\text { runaway analyses for CVDF. }\end{array}$ & $\begin{array}{l}\text { Copper Insert safety } \\
\text { classification }\end{array}$ & Quality Assurance Program & $\begin{array}{l}\text { Preventive Engineered: } \\
\text { - Copper Insert safety classification } \\
\text { Preventive Administrative: } \\
\text { - Quality Assurance Program } \\
\text { Mitigative Engineered: } \\
\text { None } \\
\text { Mitigative Administrative: } \\
\text { None }\end{array}$ & $\begin{array}{l}\text { The Copper Insert includes the } \\
\text { top and bottom screens that } \\
\text { retain the KOP material within } \\
\text { the insert. }\end{array}$ \\
\hline
\end{tabular}


Table C-1. Thermal Runaway Control Decision

\begin{tabular}{|c|c|c|c|c|c|c|c|}
\hline \multirow[b]{2}{*}{ Node } & \multirow[b]{2}{*}{ What-If? } & \multirow[b]{2}{*}{ Cause } & \multirow[b]{2}{*}{ Consequence } & \multicolumn{2}{|c|}{ Candidate Controls } & \multirow[b]{2}{*}{ Selected Controls } & \multirow[b]{2}{*}{ Remarks } \\
\hline & & & & Safety SSC Options & $\begin{array}{l}\text { Administrative Control } \\
\text { Options }\end{array}$ & & \\
\hline 4.4 & $\begin{array}{l}\text { What if the Copper } \\
\text { Insert inner } \\
\text { dimensions are } \\
\text { larger than } \\
\text { specified? }\end{array}$ & Manufacturing error & $\begin{array}{l}\text { Thermal Runaway: If the } \\
\text { Copper Insert inner dimensions } \\
\text { are larger than specified, then } \\
\text { the mass of copper will be less } \\
\text { than analyzed in the thermal } \\
\text { runaway analyses for CVDF. }\end{array}$ & $\begin{array}{l}\text { Copper Insert safety } \\
\text { classification }\end{array}$ & Quality Assurance Program & $\begin{array}{l}\text { Preventive Engineered: } \\
\text { - Copper Insert safety classification } \\
\text { Preventive Administrative: } \\
\text { - Quality Assurance Program } \\
\text { Mitigative Engineered: } \\
\text { None } \\
\text { Mitigative Administrative: } \\
\text { None }\end{array}$ & \\
\hline 4.7 & $\begin{array}{l}\text { What if a Copper } \\
\text { Insert is overfilled? }\end{array}$ & Operator error & $\begin{array}{l}\text { If a Copper Insert is overfilled, } \\
\text { then the MCO basket into which } \\
\text { it was loaded could contain a } \\
\text { larger quantity of KOP material } \\
\text { than analyzed in the Thermal } \\
\text { Runaway at CVDF. }\end{array}$ & $\begin{array}{l}\text { - Safety classification of } \\
\text { Verification Container } \\
\text { - Copper Insert safety } \\
\text { classification }\end{array}$ & $\begin{array}{l}\text { - Training Program } \\
\text { - Quality Assurance } \\
\text { Program } \\
\text { - Administrative Control TSR } \\
\text { for filling Copper Insert }\end{array}$ & $\begin{array}{l}\text { Preventive Engineered: } \\
\text { - Copper Insert safety classification } \\
\text { Preventive Administrative: } \\
\text { - Quality Assurance Program } \\
\text { - Administrative Control TSR for filling } \\
\text { Copper Insert } \\
\text { Mitigative Engineered: } \\
\text { None } \\
\text { Mitigative Administrative: } \\
\text { None }\end{array}$ & $\begin{array}{l}\text { The Administrative Control TSR } \\
\text { for filling the Copper Insert will } \\
\text { include a verification of the } \\
\text { quantity of material placed in the } \\
\text { insert. }\end{array}$ \\
\hline 4.8 & $\begin{array}{l}\text { What if there is a } \\
\text { void space in the } \\
\text { Copper Insert? }\end{array}$ & Manufacturing error & $\begin{array}{l}\text { Thermal Runaway: If there is a } \\
\text { void space in the Copper Insert, } \\
\text { then the mass of copper will be } \\
\text { less than analyzed in the } \\
\text { thermal runaway analyses for } \\
\text { CVDF. }\end{array}$ & $\begin{array}{l}\text { Copper Insert safety } \\
\text { classification }\end{array}$ & Quality Assurance Program & $\begin{array}{l}\text { Preventive Engineered: } \\
\text { - Copper Insert safety classification } \\
\text { Preventive Administrative: } \\
\text { - Quality Assurance Program } \\
\text { Mitigative Engineered: } \\
\text { None } \\
\text { Mitigative Administrative: } \\
\text { None }\end{array}$ & \\
\hline
\end{tabular}


Table C-2. Hydrogen Deflagration Control Decision

\begin{tabular}{|c|c|c|c|c|c|c|c|}
\hline \multirow[b]{2}{*}{ Node } & \multirow[b]{2}{*}{ What-If? } & \multirow{2}{*}{ Cause } & \multirow[b]{2}{*}{ Consequence } & \multicolumn{2}{|c|}{ Candidate Controls } & \multirow{2}{*}{ Selected Controls } & \multirow{2}{*}{ Remarks } \\
\hline & & & & Safety SSC Options & $\begin{array}{l}\text { Administrative Control } \\
\text { Options }\end{array}$ & & \\
\hline 1.10 & $\begin{array}{l}\text { What if the screened } \\
\text { canister openings } \\
\text { are smaller than } \\
600 \mu \mathrm{m} \text { ? }\end{array}$ & Manufacturing error & $\begin{array}{l}\text { If the openings were smaller } \\
\text { than } 600 \mu \mathrm{m} \text {, then material } \\
<600 \mu \mathrm{m} \text { would be retained and } \\
\text { subsequently transferred to the } \\
\text { Screened Separations Table. If } \\
\text { not removed at the Screened } \\
\text { Separations Table, the }<600 \mu \mathrm{m} \\
\text { material would be loaded into a } \\
\text { Verification Container and } \\
\text { eventually into an MCO. }\end{array}$ & $\begin{array}{l}\text { - Screened canister safety } \\
\text { classification } \\
\text { - Screened Separations } \\
\text { Table safety classification }\end{array}$ & $\begin{array}{l}\text { - Quality Assurance } \\
\text { Program } \\
\text { - Administrative Control TSR } \\
\text { for Screened Separations } \\
\text { Table activities }\end{array}$ & $\begin{array}{l}\text { Preventive Engineered: } \\
\text { - Screened Separations Table safety } \\
\text { classification } \\
\text { Preventive Administrative: } \\
\text { - Quality Assurance Program (as applied } \\
\text { to the Screened Separations Table) } \\
\text { - Administrative Control TSR for } \\
\text { Screened Separations Table activities } \\
\text { Mitigative Engineered: } \\
\text { None } \\
\text { Mitigative Administrative: } \\
\text { None }\end{array}$ & \\
\hline 1.12 & $\begin{array}{l}\text { What if the scale } \\
\text { erroneously } \\
\text { indicates that the } \\
\text { screened canister is } \\
\text { no longer losing } \\
\text { mass? }\end{array}$ & $\begin{array}{l}\text { - Operator error } \\
\text { - Equipment failure } \\
\text { - Calibration error }\end{array}$ & $\begin{array}{l}\text { If the scale erroneously } \\
\text { indicates that the mass of a } \\
\text { screened canister is no longer } \\
\text { decreasing, then additional } \\
\text { washing would not be } \\
\text { performed. Consequently, the } \\
\text { KOP material that is transferred } \\
\text { to the Screened Separations } \\
\text { Table would contain more } \\
\text { particles }<600 \mu \mathrm{m} \text { in size than it } \\
\text { otherwise would. If not } \\
\text { removed at the Screened } \\
\text { Separations Table, the }<600 \mu \mathrm{m} \\
\text { material would be loaded into a } \\
\text { Verification Container and } \\
\text { eventually into an MCO. }\end{array}$ & $\begin{array}{l}\text { - Scale safety classification } \\
\text { - Screened Separations } \\
\text { Table safety classification }\end{array}$ & $\begin{array}{l}\text { - Quality Assurance } \\
\text { Program } \\
\text { - Administrative Control TSR } \\
\text { for Screened Separations } \\
\text { Table activities }\end{array}$ & $\begin{array}{l}\text { Preventive Engineered: } \\
\text { - Screened Separations Table safety } \\
\text { classification } \\
\text { Preventive Administrative: } \\
\text { - Quality Assurance Program (as applied } \\
\text { to the Screened Separations Table) } \\
\text { - Administrative Control TSR for } \\
\text { Screened Separations Table activities } \\
\text { Mitigative Engineered: } \\
\text { None } \\
\text { Mitigative Administrative: } \\
\text { None }\end{array}$ & \\
\hline
\end{tabular}


Table C-2. Hydrogen Deflagration Control Decision

\begin{tabular}{|c|c|c|c|c|c|c|c|}
\hline \multirow[b]{2}{*}{ Node } & \multirow[b]{2}{*}{ What-If? } & \multirow[b]{2}{*}{ Cause } & \multirow[b]{2}{*}{ Consequence } & \multicolumn{2}{|c|}{ Candidate Controls } & \multirow[b]{2}{*}{ Selected Controls } & \multirow[b]{2}{*}{ Remarks } \\
\hline & & & & Safety SSC Options & $\begin{array}{c}\text { Administrative Control } \\
\text { Options }\end{array}$ & & \\
\hline 1.17 & $\begin{array}{l}\text { What if the screened } \\
\text { canister becomes } \\
\text { plugged? }\end{array}$ & None specified & $\begin{array}{l}\text { If the screened canister } \\
\text { becomes plugged, then } \\
<600 \mu \mathrm{m} \text { particles will not be } \\
\text { washed from the KOP material } \\
\text { in the PCM. Consequently, the } \\
\text { KOP material that is transferred } \\
\text { to the Screened Separations } \\
\text { Table would contain more } \\
\text { particles }<600 \mu \mathrm{m} \text { in size than it } \\
\text { otherwise would. If not } \\
\text { removed at the Screened } \\
\text { Separations Table, the }<600 \mu \mathrm{m} \\
\text { material would be loaded into a } \\
\text { Verification Container and } \\
\text { eventually into an MCO. }\end{array}$ & $\begin{array}{l}\text { Screened Separations Table } \\
\text { safety classification }\end{array}$ & $\begin{array}{l}\text { Administrative Control TSR } \\
\text { for Screened Separations } \\
\text { Table activities }\end{array}$ & $\begin{array}{l}\text { Preventive Engineered: } \\
\text { - Screened Separations Table safety } \\
\text { classification } \\
\text { Preventive Administrative: } \\
\text { - Administrative Control TSR for } \\
\text { Screened Separations Table activities } \\
\text { Mitigative Engineered: } \\
\text { None } \\
\text { Mitigative Administrative: } \\
\text { None }\end{array}$ & \\
\hline 2.8 & $\begin{array}{l}\text { What if foreign } \\
\text { material falls onto } \\
\text { the Screened } \\
\text { Separations Table? }\end{array}$ & None specified & $\begin{array}{l}\text { MCO Hydrogen Deflagration: If } \\
\text { the foreign material was } \\
\text { organic, and a significant } \\
\text { quantity was loaded into an } \\
\text { MCO, then oxygen generation } \\
\text { due to decomposition of the } \\
\text { organic molecules during long- } \\
\text { term storage could result in a } \\
\text { flammable concentration within } \\
\text { an MCO at the CSB. }\end{array}$ & $\begin{array}{l}\text { - Cover over Screened } \\
\text { Separations Table } \\
\text { - Low-density retrieval wand }\end{array}$ & $\begin{array}{l}\text { - Administrative control TSR } \\
\text { visual inspection for } \\
\text { organic materials } \\
\text { - Administrative control TSR } \\
\text { for determining bulk } \\
\text { density } \\
\text { - Administrative control for a } \\
\text { Foreign Material Exclusion } \\
\text { Area above the Screened } \\
\text { Separations Table }\end{array}$ & $\begin{array}{l}\text { Preventive Engineered: } \\
\text { None } \\
\text { Preventive Administrative: } \\
\text { - Administrative control TSR visual } \\
\text { inspection for organic materials } \\
\text { - Administrative control TSR for } \\
\text { determining bulk density } \\
\text { Mitigative Engineered: } \\
\text { None } \\
\text { Mitigative Administrative: } \\
\text { None }\end{array}$ & $\begin{array}{l}\text { For fuel MCO baskets, a foreign } \\
\text { material exclusion process was } \\
\text { established that required the } \\
\text { Shift Manager to be notified if } \\
\text { anything was dropped into the } \\
\text { basin water. The Shift Manager } \\
\text { would determine if the dropped } \\
\text { item had to be recovered. }\end{array}$ \\
\hline
\end{tabular}


Table C-2. Hydrogen Deflagration Control Decision

\begin{tabular}{|c|c|c|c|c|c|c|c|}
\hline \multirow[b]{2}{*}{ Node } & \multirow[b]{2}{*}{ What-If? } & \multirow[b]{2}{*}{ Cause } & \multirow[b]{2}{*}{ Consequence } & \multicolumn{2}{|c|}{ Candidate Controls } & \multirow[b]{2}{*}{ Selected Controls } & \multirow[b]{2}{*}{ Remarks } \\
\hline & & & & Safety SSC Options & $\begin{array}{l}\text { Administrative Control } \\
\text { Options }\end{array}$ & & \\
\hline 2.11 & $\begin{array}{l}\text { What if the } \\
\text { Screened } \\
\text { Separations Table } \\
\text { pump fails to } \\
\text { operate? }\end{array}$ & $\begin{array}{l}\text { - Loss of power to } \\
\text { pump } \\
\text { - Mechanical failure }\end{array}$ & $\begin{array}{l}\text { If the Screened Separations } \\
\text { Table pump fails to operate, } \\
\text { then there will be no motive } \\
\text { force besides gravity to draw } \\
<600 \mu \mathrm{m} \text { particles through the } \\
\text { screen. Particles }<600 \mu \mathrm{m} \\
\text { could be loaded into the } \\
\text { Verification Containers. }\end{array}$ & None & $\begin{array}{l}\text { Administrative Control TSR } \\
\text { for Screened Separations } \\
\text { Table activities }\end{array}$ & $\begin{array}{l}\text { Preventive Engineered: } \\
\text { None } \\
\text { Preventive Administrative: } \\
\text { - Administrative Control TSR for } \\
\text { Screened Separations Table activities } \\
\text { Mitigative Engineered: } \\
\text { None } \\
\text { Mitigative Administrative: } \\
\text { None }\end{array}$ & $\begin{array}{l}\text { During the control decision } \\
\text { meeting, it was discussed that } \\
\text { the pump suction is not required } \\
\text { for }<600 \text { particles to pass } \\
\text { through the screen. The } \\
\text { function of the pump is to } \\
\text { provide the motive force }\end{array}$ \\
\hline 2.20 & $\begin{array}{l}\text { What if the KOP } \\
\text { material is not } \\
\text { properly processed } \\
\text { on the screened } \\
\text { portion of the } \\
\text { Screened } \\
\text { Separations Table } \\
\text { (i.e., what if no } \\
\text { enough "laps" are } \\
\text { performed). }\end{array}$ & Operator error & $\begin{array}{l}\text { If the screened portion of the } \\
\text { table plugs, then particles }<600 \\
\mu m \text { could be loaded into the } \\
\text { Verification Containers and } \\
\text { eventually into an MCO. }\end{array}$ & None & $\begin{array}{l}\text { Administrative Control TSR } \\
\text { for Screened Separations } \\
\text { Table activities }\end{array}$ & $\begin{array}{l}\text { Preventive Engineered: } \\
\text { None } \\
\text { Preventive Administrative: } \\
\text { - Administrative Control TSR for } \\
\text { Screened Separations Table activities } \\
\text { Mitigative Engineered: } \\
\text { None } \\
\text { Mitigative Administrative: } \\
\text { None }\end{array}$ & \\
\hline 2.21 & $\begin{array}{l}\text { What if the screened } \\
\text { portion of the } \\
\text { Screened } \\
\text { Separations Table } \\
\text { becomes plugged? }\end{array}$ & None specified & $\begin{array}{l}\text { If the screened portion of the } \\
\text { table plugs, then particles }<600 \\
\mu \mathrm{m} \text { could be loaded into the } \\
\text { Verification Containers and } \\
\text { eventually into an MCO. }\end{array}$ & None & $\begin{array}{l}\text { Administrative Control TSR } \\
\text { for Screened Separations } \\
\text { Table activities }\end{array}$ & $\begin{array}{l}\text { Preventive Engineered: } \\
\text { None } \\
\text { Preventive Administrative: } \\
\text { - Administrative Control TSR for } \\
\text { Screened Separations Table activities } \\
\text { Mitigative Engineered: } \\
\text { None } \\
\text { Mitigative Administrative: } \\
\text { None }\end{array}$ & \\
\hline
\end{tabular}


Table C-2. Hydrogen Deflagration Control Decision

\begin{tabular}{|c|c|c|c|c|c|c|c|}
\hline \multirow{2}{*}{ Node } & \multirow{2}{*}{ What-If? } & \multirow[b]{2}{*}{ Cause } & \multirow[b]{2}{*}{ Consequence } & \multicolumn{2}{|c|}{ Candidate Controls } & \multirow[b]{2}{*}{ Selected Controls } & \multirow[b]{2}{*}{ Remarks } \\
\hline & & & & Safety SSC Options & $\begin{array}{l}\text { Administrative Control } \\
\text { Options }\end{array}$ & & \\
\hline 2.22 & $\begin{array}{l}\text { What if the openings } \\
\text { of the screened } \\
\text { portion of the } \\
\text { Screened } \\
\text { Separations Table } \\
\text { are smaller than } 600 \\
\mu m ?\end{array}$ & Manufacturing error & $\begin{array}{l}\text { If the openings of the screened } \\
\text { portion of the table are smaller } \\
\text { than } 600 \mu \mathrm{m} \text {, then particles }< \\
600 \mu \mathrm{m} \text { could be loaded into the } \\
\text { Verification Containers and } \\
\text { eventually into an MCO. }\end{array}$ & $\begin{array}{l}\text { Screened separation table } \\
\text { safety classification }\end{array}$ & Quality Assurance Program & $\begin{array}{l}\text { Preventive Engineered: } \\
\text { - Screened Separations Table safety } \\
\text { classification } \\
\text { Preventive Administrative: } \\
\text { - Quality Assurance Program } \\
\text { Mitigative Engineered: } \\
\text { None } \\
\text { Mitigative Administrative: } \\
\text { None }\end{array}$ & \\
\hline 3.7 & $\begin{array}{l}\text { What if foreign } \\
\text { material gets into the } \\
\text { Verification } \\
\text { Container? }\end{array}$ & $\begin{array}{l}\text { Feed chute plug not } \\
\text { installed and foreign } \\
\text { material present in } \\
\text { vicinity of Screened } \\
\text { Separations Table }\end{array}$ & $\begin{array}{l}\text { MCO Hydrogen Deflagration: If } \\
\text { the foreign material was } \\
\text { organic, and a significant } \\
\text { quantity was loaded into an } \\
\text { MCO, then oxygen generation } \\
\text { due to decomposition of the } \\
\text { organic molecules during long- } \\
\text { term storage could result in a } \\
\text { flammable concentration within } \\
\text { an MCO at CSB. }\end{array}$ & $\begin{array}{l}\text { - Verification Container cover } \\
\text { - Low-density retrieval wand }\end{array}$ & $\begin{array}{l}\text { - Administrative control TSR } \\
\text { visual inspection of the } \\
\text { Verification Container } \\
\text { - Administrative control for a } \\
\text { Foreign Material Exclusion } \\
\text { Area above the Screened } \\
\text { Separations Table }\end{array}$ & $\begin{array}{l}\text { Preventive Engineered: } \\
\text { None } \\
\text { Preventive Administrative: } \\
\text { - Administrative control TSR for visual } \\
\text { inspection of Verification Container } \\
\text { Mitigative Engineered: } \\
\text { None } \\
\text { Mitigative Administrative: } \\
\text { None }\end{array}$ & $\begin{array}{l}\text { For fuel MCO baskets, a foreign } \\
\text { material exclusion process was } \\
\text { established that required the } \\
\text { Shift Manager to be notified if } \\
\text { anything was dropped into the } \\
\text { basin water. The Shift Manager } \\
\text { would determine if the dropped } \\
\text { item had to be recovered. }\end{array}$ \\
\hline
\end{tabular}


Table C-3. Overpressurization Control Decision

\begin{tabular}{|c|c|c|c|c|c|c|c|}
\hline \multirow{2}{*}{ Node } & \multirow{2}{*}{ What-If? } & \multirow[b]{2}{*}{ Cause } & \multirow[b]{2}{*}{ Consequence } & \multicolumn{2}{|c|}{ Candidate Controls } & \multirow[b]{2}{*}{ Selected Controls } & \multirow[b]{2}{*}{ Remarks } \\
\hline & & & & Safety SSC Options & $\begin{array}{c}\text { Administrative Control } \\
\text { Options }\end{array}$ & & \\
\hline 1.10 & $\begin{array}{l}\text { What if the screened } \\
\text { canister openings } \\
\text { are smaller than } \\
600 \mu \mathrm{m} \text { ? }\end{array}$ & Manufacturing error & $\begin{array}{l}\text { If the openings were smaller } \\
\text { than } 600 \mu \mathrm{m} \text {, then material } \\
<600 \mu \mathrm{m} \text { would be retained and } \\
\text { subsequently transferred to the } \\
\text { Screened Separations Table. If } \\
\text { not removed at the Screened } \\
\text { Separations Table, the }<600 \mu \mathrm{m} \\
\text { material would be loaded into a } \\
\text { Verification Container and } \\
\text { eventually into an MCO. } \\
\end{array}$ & $\begin{array}{l}\text { - Screened canister safety } \\
\text { classification } \\
\text { - Screened Separations } \\
\text { Table safety classification }\end{array}$ & $\begin{array}{l}\text { - Quality Assurance } \\
\text { Program } \\
\text { - Administrative Control TSR } \\
\text { for Screened Separations } \\
\text { Table activities }\end{array}$ & $\begin{array}{l}\text { Preventive Engineered: } \\
\text { - Screened Separations Table safety } \\
\text { classification } \\
\text { Preventive Administrative: } \\
\text { - Quality Assurance Program (as applied } \\
\text { to the Screened Separations Table) } \\
\text { - Administrative Control TSR for } \\
\text { Screened Separations Table activities } \\
\text { Mitigative Engineered: } \\
\text { None } \\
\text { Mitigative Administrative: } \\
\text { None }\end{array}$ & \\
\hline 1.12 & $\begin{array}{l}\text { What if the scale } \\
\text { erroneously } \\
\text { indicates that the } \\
\text { screened canister is } \\
\text { no longer losing } \\
\text { mass? }\end{array}$ & $\begin{array}{l}\text { - Operator error } \\
\text { - Equipment failure } \\
\text { - Calibration error }\end{array}$ & $\begin{array}{l}\text { If the scale erroneously } \\
\text { indicates that the mass of a } \\
\text { screened canister is no longer } \\
\text { decreasing, then additional } \\
\text { washing would not be } \\
\text { performed. Consequently, the } \\
\text { KOP material that is transferred } \\
\text { to the Screened Separations } \\
\text { Table would contain more } \\
\text { particles }<600 \mu \mathrm{m} \text { in size than it } \\
\text { otherwise would. If not } \\
\text { removed at the Screened } \\
\text { Separations Table, the <600 } \mu \mathrm{m} \\
\text { material would be loaded into a } \\
\text { Verification Container and } \\
\text { eventually into an MCO. }\end{array}$ & $\begin{array}{l}\text { - Scale safety classification } \\
\text { - Screened Separations } \\
\text { Table safety classification }\end{array}$ & $\begin{array}{l}\text { - Quality Assurance } \\
\text { Program } \\
\text { - Administrative Control TSR } \\
\text { for Screened Separations } \\
\text { Table activities }\end{array}$ & $\begin{array}{l}\text { Preventive Engineered: } \\
\text { - Screened Separations Table safety } \\
\text { classification } \\
\text { Preventive Administrative: } \\
\text { - Quality Assurance Program (as applied } \\
\text { to the Screened Separations Table) } \\
\text { - Administrative Control TSR for } \\
\text { Screened Separations Table activities } \\
\text { Mitigative Engineered: } \\
\text { None } \\
\text { Mitigative Administrative: } \\
\text { None }\end{array}$ & \\
\hline
\end{tabular}


Table C-3. Overpressurization Control Decision

\begin{tabular}{|c|c|c|c|c|c|c|c|}
\hline \multirow[b]{2}{*}{ Node } & \multirow[b]{2}{*}{ What-If? } & \multirow[b]{2}{*}{ Cause } & \multirow[b]{2}{*}{ Consequence } & \multicolumn{2}{|c|}{ Candidate Controls } & \multirow[b]{2}{*}{ Selected Controls } & \multirow[b]{2}{*}{ Remarks } \\
\hline & & & & Safety SSC Options & $\begin{array}{c}\text { Administrative Control } \\
\text { Options }\end{array}$ & & \\
\hline 1.17 & $\begin{array}{l}\text { What if the screened } \\
\text { canister becomes } \\
\text { plugged? }\end{array}$ & None specified & $\begin{array}{l}\text { If the screened canister } \\
\text { becomes plugged, then } \\
<600 \mu \mathrm{m} \text { particles will not be } \\
\text { washed from the KOP material } \\
\text { in the PCM. Consequently, the } \\
\text { KOP material that is transferred } \\
\text { to the Screened Separations } \\
\text { Table would contain more } \\
\text { particles }<600 \mu \mathrm{m} \text { in size than it } \\
\text { otherwise would. If not } \\
\text { removed at the Screened } \\
\text { Separations Table, the }<600 \mu \mathrm{m} \\
\text { material would be loaded into a } \\
\text { Verification Container and } \\
\text { eventually into an MCO. }\end{array}$ & $\begin{array}{l}\text { Screened Separations Table } \\
\text { safety classification }\end{array}$ & $\begin{array}{l}\text { Administrative Control TSR } \\
\text { for Screened Separations } \\
\text { Table activities }\end{array}$ & $\begin{array}{l}\text { Preventive Engineered: } \\
\text { - Screened Separations Table safety } \\
\text { classification } \\
\text { Preventive Administrative: } \\
\text { - Administrative Control TSR for } \\
\text { Screened Separations Table activities } \\
\text { Mitigative Engineered: } \\
\text { None } \\
\text { Mitigative Administrative: } \\
\text { None }\end{array}$ & \\
\hline 2.8 & $\begin{array}{l}\text { What if foreign } \\
\text { material falls onto } \\
\text { the Screened } \\
\text { Separations Table? }\end{array}$ & None specified & $\begin{array}{l}\text { MCO Overpressurization: If the } \\
\text { foreign material was organic, } \\
\text { and a significant quantity was } \\
\text { loaded into an MCO, then gas } \\
\text { generation due to } \\
\text { decomposition of organic } \\
\text { molecules during long-term } \\
\text { storage could result in } \\
\text { overpressurization of the MCO } \\
\text { at the CSB }\end{array}$ & $\begin{array}{l}\text { Cover over Screened } \\
\text { Separations Table }\end{array}$ & $\begin{array}{l}\text { - Administrative control TSR } \\
\text { visual inspection for } \\
\text { organic materials } \\
\text { - Administrative control TSR } \\
\text { for determining bulk } \\
\text { density } \\
\text { - Administrative control for a } \\
\text { Foreign Material Exclusion } \\
\text { Area above the Screened } \\
\text { Separations Table }\end{array}$ & $\begin{array}{l}\text { Preventive Engineered: } \\
\text { None } \\
\text { Preventive Administrative: } \\
\text { - Administrative control TSR visual } \\
\text { inspection for organic materials } \\
\text { - Administrative control TSR for } \\
\text { determining bulk density } \\
\text { Mitigative Engineered: } \\
\text { None } \\
\text { Mitigative Administrative: } \\
\text { None }\end{array}$ & $\begin{array}{l}\text { For fuel MCO baskets, a foreign } \\
\text { material exclusion process was } \\
\text { established that required the } \\
\text { Shift Manager to be notified if } \\
\text { anything was dropped into the } \\
\text { basin water. The Shift Manager } \\
\text { would determine if the dropped } \\
\text { item had to be recovered. }\end{array}$ \\
\hline
\end{tabular}


Table C-3. Overpressurization Control Decision

\begin{tabular}{|c|c|c|c|c|c|c|c|}
\hline \multirow{2}{*}{ Node } & \multirow{2}{*}{ What-If? } & \multirow{2}{*}{ Cause } & \multirow{2}{*}{ Consequence } & \multicolumn{2}{|c|}{ Candidate Controls } & \multirow{2}{*}{ Selected Controls } & \multirow{2}{*}{ Remarks } \\
\hline & & & & Safety SSC Options & $\begin{array}{c}\text { Administrative Control } \\
\text { Options }\end{array}$ & & \\
\hline 2.11 & $\begin{array}{l}\text { What if the } \\
\text { Screened } \\
\text { Separations Table } \\
\text { pump fails to } \\
\text { operate? }\end{array}$ & $\begin{array}{l}\text { - Loss of power to } \\
\text { pump } \\
\text { - Mechanical failure }\end{array}$ & $\begin{array}{l}\text { If the Screened Separations } \\
\text { Table pump fails to operate, } \\
\text { then there will be no motive } \\
\text { force besides gravity to draw } \\
<600 \mu \mathrm{m} \text { particles through the } \\
\text { screen. Particles }<600 \mu \mathrm{m} \\
\text { could be loaded into the } \\
\text { Verification Containers. }\end{array}$ & None & $\begin{array}{l}\text { Administrative Control TSR } \\
\text { for Screened Separations } \\
\text { Table activities }\end{array}$ & $\begin{array}{l}\text { Preventive Engineered: } \\
\text { None } \\
\text { Preventive Administrative: } \\
\text { - Administrative Control TSR for } \\
\text { Screened Separations Table activities } \\
\text { Mitigative Engineered: } \\
\text { None } \\
\text { Mitigative Administrative: } \\
\text { None }\end{array}$ & \\
\hline 2.20 & $\begin{array}{l}\text { What if the KOP } \\
\text { material is not } \\
\text { properly processed } \\
\text { on the screened } \\
\text { portion of the } \\
\text { Screened } \\
\text { Separations Table } \\
\text { (i.e., what if no } \\
\text { enough "laps" are } \\
\text { performed). }\end{array}$ & Operator error & $\begin{array}{l}\text { If the screened portion of the } \\
\text { table plugs, then particles }<600 \\
\text { um could be loaded into the } \\
\text { Verification Containers and } \\
\text { eventually into an MCO. }\end{array}$ & None & $\begin{array}{l}\text { Administrative Control TSR } \\
\text { for Screened Separations } \\
\text { Table activities }\end{array}$ & $\begin{array}{l}\text { Preventive Engineered: } \\
\text { None } \\
\text { Preventive Administrative: } \\
\text { - Administrative Control TSR for } \\
\text { Screened Separations Table activities } \\
\text { Mitigative Engineered: } \\
\text { None } \\
\text { Mitigative Administrative: } \\
\text { None }\end{array}$ & \\
\hline 2.21 & $\begin{array}{l}\text { What if the screened } \\
\text { portion of the } \\
\text { Screened } \\
\text { Separations Table } \\
\text { becomes plugged? }\end{array}$ & None specified & $\begin{array}{l}\text { If the screened portion of the } \\
\text { table plugs, then particles }<600 \\
\mu m \text { could be loaded into the } \\
\text { Verification Containers and } \\
\text { eventually into an MCO. }\end{array}$ & None & $\begin{array}{l}\text { Administrative Control TSR } \\
\text { for Screened Separations } \\
\text { Table activities }\end{array}$ & $\begin{array}{l}\text { Preventive Engineered: } \\
\text { None } \\
\text { Preventive Administrative: } \\
\text { - Administrative Control TSR for } \\
\text { Screened Separations Table activities } \\
\text { Mitigative Engineered: } \\
\text { None } \\
\text { Mitigative Administrative: } \\
\text { None }\end{array}$ & \\
\hline
\end{tabular}


Table C-3. Overpressurization Control Decision

\begin{tabular}{|c|c|c|c|c|c|c|c|}
\hline \multirow[b]{2}{*}{ Node } & \multirow[b]{2}{*}{ What-If? } & \multirow[b]{2}{*}{ Cause } & \multirow[b]{2}{*}{ Consequence } & \multicolumn{2}{|c|}{ Candidate Controls } & \multirow[b]{2}{*}{ Selected Controls } & \multirow[b]{2}{*}{ Remarks } \\
\hline & & & & Safety SSC Options & $\begin{array}{c}\text { Administrative Control } \\
\text { Options }\end{array}$ & & \\
\hline 2.22 & $\begin{array}{l}\text { What if the openings } \\
\text { of the screened } \\
\text { portion of the } \\
\text { Screened } \\
\text { Separations Table } \\
\text { are smaller than } 600 \\
\mu m ?\end{array}$ & Manufacturing error & $\begin{array}{l}\text { If the openings of the screened } \\
\text { portion of the table are smaller } \\
\text { than } 600 \mu \mathrm{m} \text {, then particles }< \\
600 \mu \mathrm{m} \text { could be loaded into the } \\
\text { Verification Containers and } \\
\text { eventually into an MCO. }\end{array}$ & $\begin{array}{l}\text { Screened separation table } \\
\text { safety classification }\end{array}$ & Quality Assurance Program & $\begin{array}{l}\text { Preventive Engineered: } \\
\text { - Screened Separations Table safety } \\
\text { classification } \\
\text { Preventive Administrative: } \\
\text { - Quality Assurance Program } \\
\text { Mitigative Engineered: } \\
\text { None } \\
\text { Mitigative Administrative: } \\
\text { None }\end{array}$ & \\
\hline 3.5 & $\begin{array}{l}\text { What if the } \\
\text { Verification } \\
\text { Container } \\
\text { dimensions are } \\
\text { incorrect? }\end{array}$ & Manufacturing error & $\begin{array}{l}\text { MCO Overpressurization: If the } \\
\text { Verification Container is larger } \\
\text { than specified, then a lower- } \\
\text { than-actual volume will be } \\
\text { recorded. As a result, the } \\
\text { calculated bulk density will be } \\
\text { higher than actual. This could } \\
\text { increase the quantity of water in } \\
\text { the MCO which could result in } \\
\text { MCO overpressurization during } \\
\text { long-term storage at CSB. }\end{array}$ & $\begin{array}{l}\text { Verification Container safety } \\
\text { classification }\end{array}$ & Quality Assurance Program & $\begin{array}{l}\text { Preventive Engineered: } \\
\text { - Verification Container safety } \\
\text { classification } \\
\text { Preventive Administrative: } \\
\text { - Quality Assurance Program } \\
\text { Mitigative Engineered: } \\
\text { None } \\
\text { Mitigative Administrative: } \\
\text { None }\end{array}$ & \\
\hline 3.6 & $\begin{array}{l}\text { What if the } \\
\text { Verification } \\
\text { Container tare } \\
\text { weight is incorrectly } \\
\text { measured or } \\
\text { recorded? }\end{array}$ & $\begin{array}{l}\text { - Operator error } \\
\text { - Calibration error }\end{array}$ & $\begin{array}{l}\text { MCO Overpressurization: If the } \\
\text { recorded Verification Container } \\
\text { tare weight is less than actual, } \\
\text { then the calculated bulk density } \\
\text { will be higher than actual. This } \\
\text { could increase the quantity of } \\
\text { water in the MCO which could } \\
\text { result in MCO } \\
\text { overpressurization during long- } \\
\text { term storage at CSB. }\end{array}$ & $\begin{array}{l}\text { Safety classification of } \\
\text { instrumentation for } \\
\text { measuring tare weight }\end{array}$ & $\begin{array}{l}\text { - Administrative Control TSR } \\
\text { for making measurement } \\
\text { - Quality Assurance } \\
\text { Program } \\
\text { - Training Program }\end{array}$ & $\begin{array}{l}\text { Preventive Engineered: } \\
\text { Weight instrumentation safety } \\
\text { classification } \\
\text { Preventive Administrative: } \\
\text { - Quality Assurance Program } \\
\text { - Administrative control TSR for making } \\
\text { weight measurement } \\
\text { Mitigative Engineered: } \\
\text { None } \\
\text { Mitigative Administrative: } \\
\text { None }\end{array}$ & \\
\hline
\end{tabular}


Table C-3. Overpressurization Control Decision

\begin{tabular}{|c|c|c|c|c|c|c|c|}
\hline \multirow[b]{2}{*}{ Node } & \multirow[b]{2}{*}{ What-If? } & \multirow[b]{2}{*}{ Cause } & \multirow[b]{2}{*}{ Consequence } & \multicolumn{2}{|c|}{ Candidate Controls } & \multirow[b]{2}{*}{ Selected Controls } & \multirow[b]{2}{*}{ Remarks } \\
\hline & & & & Safety SSC Options & $\begin{array}{c}\text { Administrative Control } \\
\text { Options }\end{array}$ & & \\
\hline 3.7 & $\begin{array}{l}\text { What if foreign } \\
\text { material gets into the } \\
\text { Verification } \\
\text { Container? }\end{array}$ & $\begin{array}{l}\text { Feed chute plug not } \\
\text { installed and foreign } \\
\text { material present in } \\
\text { vicinity of Screened } \\
\text { Separations Table }\end{array}$ & $\begin{array}{l}\text { MCO Overpressurization: If the } \\
\text { foreign material was organic, } \\
\text { and a significant quantity was } \\
\text { loaded into an MCO, then gas } \\
\text { generation due to } \\
\text { decomposition of organic } \\
\text { molecules during long-term } \\
\text { storage could result in } \\
\text { overpressurization of the MCO } \\
\text { at CSB. }\end{array}$ & Verification Container cover & $\begin{array}{l}\text { - Administrative control TSR } \\
\text { visual inspection of the } \\
\text { Verification Container } \\
\text { - Administrative control for a } \\
\text { Foreign Material Exclusion } \\
\text { Area above the Screened } \\
\text { Separations Table }\end{array}$ & $\begin{array}{l}\text { Preventive Engineered: } \\
\text { None } \\
\text { Preventive Administrative: } \\
\text { - Administrative control TSR for visual } \\
\text { inspection of Verification Container } \\
\text { Mitigative Engineered: } \\
\text { None } \\
\text { Mitigative Administrative: } \\
\text { None }\end{array}$ & $\begin{array}{l}\text { For fuel MCO baskets, a foreign } \\
\text { material exclusion process was } \\
\text { established that required the } \\
\text { Shift Manager to be notified if } \\
\text { anything was dropped into the } \\
\text { basin water. The Shift Manager } \\
\text { would determine if the dropped } \\
\text { item had to be recovered. }\end{array}$ \\
\hline 3.14 & $\begin{array}{l}\text { What if the } \\
\text { instrument used for } \\
\text { measuring the mass } \\
\text { of the Verification } \\
\text { Container reads } \\
\text { higher than actual? }\end{array}$ & $\begin{array}{l}\text { - Equipment } \\
\text { malfunction } \\
\text { - Calibration error }\end{array}$ & $\begin{array}{l}\text { MCO Overpressurization: If the } \\
\text { instrument reads a higher than } \\
\text { actual mass, then the calculated } \\
\text { bulk density will be higher than } \\
\text { actual. This could increase the } \\
\text { quantity of water in the MCO } \\
\text { which could result in MCO } \\
\text { overpressurization during long- } \\
\text { term storage at CSB. }\end{array}$ & $\begin{array}{l}\text { Safety classification of } \\
\text { instrumentation for } \\
\text { measuring tare weight }\end{array}$ & $\begin{array}{l}\text { - Administrative Control TSR } \\
\text { for making measurement } \\
\text { - Quality Assurance } \\
\text { Program } \\
\text { - Training Program }\end{array}$ & $\begin{array}{l}\text { Preventive Engineered: } \\
\text { Weight instrumentation safety } \\
\text { classification } \\
\text { Preventive Administrative: } \\
\text { - Quality Assurance Program } \\
\text { - Administrative control TSR for making } \\
\text { weight measurement } \\
\text { Mitigative Engineered: } \\
\text { None } \\
\text { Mitigative Administrative: } \\
\text { None }\end{array}$ & \\
\hline 3.16 & $\begin{array}{l}\text { What if the operator } \\
\text { records a higher } \\
\text { than actual mass? }\end{array}$ & Operator error & $\begin{array}{l}\text { MCO Overpressurization: If the } \\
\text { operator records a higher than } \\
\text { actual mass, then the calculated } \\
\text { bulk density will be higher than } \\
\text { actual. This could increase the } \\
\text { quantity of water in the MCO } \\
\text { which could result in MCO } \\
\text { overpressurization during long- } \\
\text { term storage at CSB. }\end{array}$ & None & $\begin{array}{l}\text { - Administrative Control TSR } \\
\text { for determining bulk } \\
\text { density } \\
\text { - Training Program }\end{array}$ & $\begin{array}{l}\text { Preventive Engineered: } \\
\text { None } \\
\text { Preventive Administrative: } \\
\text { - Administrative Control TSR for } \\
\text { determining bulk density } \\
\text { Mitigative Engineered: } \\
\text { None } \\
\text { Mitigative Administrative: } \\
\text { None }\end{array}$ & \\
\hline
\end{tabular}


Table C-3. Overpressurization Control Decision

\begin{tabular}{|c|c|c|c|c|c|c|c|}
\hline \multirow[b]{2}{*}{ Node } & \multirow[b]{2}{*}{ What-If? } & \multirow[b]{2}{*}{ Cause } & \multirow[b]{2}{*}{ Consequence } & \multicolumn{2}{|c|}{ Candidate Controls } & \multirow[b]{2}{*}{ Selected Controls } & \multirow[b]{2}{*}{ Remarks } \\
\hline & & & & Safety SSC Options & $\begin{array}{l}\text { Administrative Control } \\
\text { Options }\end{array}$ & & \\
\hline 3.19 & $\begin{array}{l}\text { What if the operator } \\
\text { records a lower than } \\
\text { actual volume? }\end{array}$ & Operator error & $\begin{array}{l}\text { MCO Overpressurization: If the } \\
\text { operator records a lower than } \\
\text { actual volume, then the } \\
\text { calculated bulk density will be } \\
\text { higher than actual. This could } \\
\text { increase the quantity of water in } \\
\text { the MCO which could result in } \\
\text { MCO overpressurization during } \\
\text { long-term storage at CSB. }\end{array}$ & None & $\begin{array}{l}\text { - Administrative Control TSR } \\
\text { for determining bulk } \\
\text { density } \\
\text { - Training Program }\end{array}$ & $\begin{array}{l}\text { Preventive Engineered: } \\
\text { None } \\
\text { Preventive Administrative: } \\
\text { - Administrative Control TSR for } \\
\text { determining bulk density } \\
\text { Mitigative Engineered: } \\
\text { None } \\
\text { Mitigative Administrative: } \\
\text { None }\end{array}$ & \\
\hline 3.20 & $\begin{array}{l}\text { What if the ruler } \\
\text { scale/Verification } \\
\text { Container are } \\
\text { misaligned? }\end{array}$ & None specified & $\begin{array}{l}\text { MCO Overpressurization: If the } \\
\text { ruler scale is misaligned such } \\
\text { that a lower than actual volume } \\
\text { is recorded, then the calculated } \\
\text { bulk density will be higher than } \\
\text { actual. This could increase the } \\
\text { quantity of water in the MCO } \\
\text { which could result in MCO } \\
\text { overpressurization during long- } \\
\text { term storage at CSB. }\end{array}$ & $\begin{array}{l}\text { Verification Container safety } \\
\text { classification }\end{array}$ & $\begin{array}{l}\text { - Administrative Control TSR } \\
\text { for making volume } \\
\text { measurement } \\
\text { - Quality Assurance } \\
\text { Program } \\
\text { - Training Program }\end{array}$ & $\begin{array}{l}\text { Preventive Engineered: } \\
\text { - Verification Container safety } \\
\text { classification } \\
\text { Preventive Administrative: } \\
\text { - Administrative control TSR for making } \\
\text { volume measurement } \\
\text { - Quality Assurance Program } \\
\text { Mitigative Engineered: } \\
\text { None } \\
\text { Mitigative Administrative: } \\
\text { None }\end{array}$ & \\
\hline 3.21 & $\begin{array}{l}\text { What if the ruler } \\
\text { scale is inaccurate? }\end{array}$ & Manufacturing error & $\begin{array}{l}\text { MCO Overpressurization: If the } \\
\text { ruler scale is inaccurate such } \\
\text { that a lower than actual volume } \\
\text { is recorded, then the calculated } \\
\text { bulk density will be higher than } \\
\text { actual. This could increase the } \\
\text { quantity of water in the MCO } \\
\text { which could result in MCO } \\
\text { overpressurization during long- } \\
\text { term storage. }\end{array}$ & $\begin{array}{l}\text { Verification Container safety } \\
\text { classification }\end{array}$ & $\begin{array}{l}\text { - Administrative Control TSR } \\
\text { for making volume } \\
\text { measurement } \\
\text { - Quality Assurance } \\
\text { - Program } \\
\text { - Training Program }\end{array}$ & $\begin{array}{l}\text { Preventive Engineered: } \\
\text { - Verification Container safety } \\
\text { classification } \\
\text { Preventive Administrative: } \\
\text { - Administrative control TSR for making } \\
\text { - Qolume measurement } \\
\text { Quality Assurance Program } \\
\text { Mitigative Engineered: } \\
\text { None } \\
\text { Mitigative Administrative: }\end{array}$ & \\
\hline
\end{tabular}


Table C-3. Overpressurization Control Decision

\begin{tabular}{|c|c|c|c|c|c|c|c|}
\hline \multirow[b]{2}{*}{ Node } & \multirow[b]{2}{*}{ What-If? } & \multirow[b]{2}{*}{ Cause } & \multirow[b]{2}{*}{ Consequence } & \multicolumn{2}{|c|}{ Candidate Controls } & \multirow[b]{2}{*}{ Selected Controls } & \multirow[b]{2}{*}{ Remarks } \\
\hline & & & & Safety SSC Options & $\begin{array}{c}\text { Administrative Control } \\
\text { Options }\end{array}$ & & \\
\hline & & & & & & None & \\
\hline 3.22 & $\begin{array}{l}\text { What if the } \\
\text { calculated bulk } \\
\text { density is higher } \\
\text { than actual? }\end{array}$ & $\begin{array}{l}\text { Nodes 3.5, 3.6, 3.14, } \\
3.16,3.19,3.20,3.21\end{array}$ & $\begin{array}{l}\text { MCO Overpressurization: If the } \\
\text { calculated bulk density is higher } \\
\text { than actual, than low density } \\
\text { material could be loaded into an } \\
\text { MCO basket. This could } \\
\text { increase the quantity of water in } \\
\text { the MCO which could result in } \\
\text { MCO overpressurization during } \\
\text { long-term storage at CSB. }\end{array}$ & $\begin{array}{l}\text { - Safety classification of } \\
\text { instrumentation for } \\
\text { measuring mass } \\
\text { - Verification Container } \\
\text { safety classification }\end{array}$ & $\begin{array}{l}\text { - Administrative Control TSR } \\
\text { for determining bulk } \\
\text { density } \\
\text { - Quality Assurance } \\
\text { Program } \\
\text { - Training Program }\end{array}$ & $\begin{array}{l}\text { Preventive Engineered: } \\
\text { - Safety classification of instrumentation } \\
\text { for measuring mass } \\
\text { - Verification Container safety } \\
\text { classification } \\
\text { Preventive Administrative: } \\
\text { - Administrative control TSR for making } \\
\text { weight measurement } \\
\text { - Administrative control TSR for making } \\
\text { volume measurement } \\
\text { - Administrative Control TSR for } \\
\text { determining bulk density } \\
\text { - Quality Assurance Program } \\
\text { Mitigative Engineered: } \\
\text { None } \\
\text { Mitigative Administrative: } \\
\text { None }\end{array}$ & \\
\hline 4.7 & $\begin{array}{l}\text { What if a Copper } \\
\text { Insert is overfilled? }\end{array}$ & Operator error & $\begin{array}{l}\text { If a Copper Insert is overfilled, } \\
\text { then the MCO basket into which } \\
\text { it was loaded could contain a } \\
\text { larger quantity of KOP material } \\
\text { than analyzed in the Thermal } \\
\text { Runaway at CVDF and the } \\
\text { Ovepressurization and } \\
\text { Hydrogen Deflagration analyses } \\
\text { at CVDF and CSB. }\end{array}$ & $\begin{array}{l}\text { - Safety classification of } \\
\text { Verification Container } \\
\text { - Copper Insert safety } \\
\text { classification }\end{array}$ & $\begin{array}{l}\text { - Training Program } \\
\text { - Quality Assurance } \\
\text { Program } \\
\text { - Administrative Control TSR } \\
\text { for filling Copper Insert }\end{array}$ & $\begin{array}{l}\text { Preventive Engineered: } \\
\text { - Copper Insert safety classification } \\
\text { Preventive Administrative: } \\
\text { - Quality Assurance Program } \\
\text { Mitigative Engineered: } \\
\text { None } \\
\text { Mitigative Administrative: } \\
\text { None }\end{array}$ & \\
\hline
\end{tabular}


Table C-3. Overpressurization Control Decision

\begin{tabular}{|c|c|c|c|c|c|c|c|}
\hline \multirow{2}{*}{ Node } & \multirow{2}{*}{ What-If? } & \multirow{2}{*}{ Cause } & \multirow[b]{2}{*}{ Consequence } & \multicolumn{2}{|c|}{ Candidate Controls } & \multirow[b]{2}{*}{ Selected Controls } & \multirow[b]{2}{*}{ Remarks } \\
\hline & & & & Safety SSC Options & $\begin{array}{l}\text { Administrative Control } \\
\text { Options }\end{array}$ & & \\
\hline 4.12 & $\begin{array}{l}\text { What if there is } \\
\text { foreign material in } \\
\text { the insert prior to } \\
\text { placing the screen } \\
\text { on the insert? }\end{array}$ & None specified & $\begin{array}{l}\text { MCO Overpressurization: If the } \\
\text { foreign material was organic, } \\
\text { and a significant quantity was } \\
\text { loaded into an MCO, then gas } \\
\text { generation due to } \\
\text { decomposition of organic } \\
\text { molecules during long-term } \\
\text { storage could result in } \\
\text { overpressurization of the MCO } \\
\text { at CSB. }\end{array}$ & Copper Insert cover & $\begin{array}{l}\text { - Administrative control TSR } \\
\text { visual inspection of the } \\
\text { Copper Insert } \\
\text { - Administrative control for a } \\
\text { Foreign Material Exclusion } \\
\text { Area above the Screened } \\
\text { Separations Table }\end{array}$ & $\begin{array}{l}\text { Preventive Engineered: } \\
\text { None } \\
\text { Preventive Administrative: } \\
\text { - Administrative control TSR for visual } \\
\text { inspection of Copper Insert } \\
\text { Mitigative Engineered: } \\
\text { None } \\
\text { Mitigative Administrative: } \\
\text { None }\end{array}$ & $\begin{array}{l}\text { For fuel MCO baskets, a foreign } \\
\text { material exclusion process was } \\
\text { established that required the } \\
\text { Shift Manager to be notified if } \\
\text { anything was dropped into the } \\
\text { basin water. The Shift Manager } \\
\text { would determine if the dropped } \\
\text { item had to be recovered. }\end{array}$ \\
\hline
\end{tabular}


